\title{
FLANK MARGIN CAVE DEVELOPMENT IN TELOGENETIC LIMESTONES OF NEW ZEALAND
}

\author{
JAME TIPA “FLANK MARGIN" V TELOGENETSKIH APNENCIH \\ NOVE ZELANDIJE
}

\author{
John E. MYLROIE ${ }^{1}$, Joan R. MYLROIE ${ }^{1}$ \& Campbell S. NELSON ${ }^{2}$
}

\begin{abstract}
UDC 552.54:551.3.051(931)

John E. Mylroie, Joan R. Mylroie \& Campbell S. Nelson: Flank Margin Cave Development in Telogenetic Limestones of New Zealand

Coastal limestone outcrops, typically with advanced levels of diagenetic maturity (i.e., are telogenetic carbonates), were examined on North Island (Raglan Harbour, Kawhia Harbour, Napier, and Waipu Cove) and South Island (Pohara, Paturau River, Punakaiki, Kakanui, and Kaikoura), New Zealand, to determine if flank margin caves, produced by mixing dissolution, were present. In coastal settings, caves in carbonate rock can be the outcome of pseudokarst process, primarily wave erosion, as well as karst processes not associated with fresh and sea-water mixing such as epikarst features and conduit-flow stream caves. Flank margin caves were successfully differentiated from other cave types by the following criteria: phreatic dissolutional morphologies at the wall rock and chamber scales; absence of highvelocity, turbulent-flow wall sculpture and sediment deposits; and lack of integration of adjacent caves into a continuous flow path. The active tectonics of New Zealand creates a variable sealevel situation. The relatively short time of sea-level stability limits the size of the New Zealand flank margin caves compared to tectonically-stable environments, such as the Bahamas, where glacioeustasy alone controls sea-level stability. Uplift events can be identified as slow and steady when the flank margin caves are uniformly elongated in the vertical direction, and episodic when the flank margin caves show widening and tube development at discrete horizons that cut across rock structure. New Zealand flank margin caves contain information on uplift duration and rates independent of other commonly used measures, and therefore can provide a calibration to other methods.
\end{abstract}

Key Words: flank margin caves, New Zealand, telogenetic carbonates, coastal caves.
Izvleček

UDK 552.54:551.3.051(931)

John E. Mylroie, Joan R. Mylroie \& Campbell S. Nelson: Jame tipa "Flank margin" v telogenetskih apnencih Nove Zelandije $\mathrm{Z}$ namenom, da odkrijemo prisotnost jam nastalih $\mathrm{v}$ priobalnem pasu mešanja slane in sladke vode (jame tipa "Flank margin”), smo raziskovali diagenetsko zrele apnence Severnega (pristanišče Raglan in Kawhia, drage Napier in Waipu) in Južnega otoka (Pohara, reka Paturau, Piunakaiki, Kakanui in Kaikoura) Nove Zelandije. Na obalnih področjih so jame v karbonatih lahko rezultat različnih psevdokraških (npr. erozija valovanja) in kraških procesov, ki niso povezani $\mathrm{z}$ mešanjem slane in sladke vode (npr. epikraške oblike in jame nastale $\mathrm{z}$ meteorno kraško drenažo). Jame tipa "Flank margin" smo uspešno ločili od ostalih tipov jam z opazovanjem naslednjih značilnosti: morfologija freatičnih skalnih oblik v različnih merilih, odsotnost skalnih oblik in sedimentov, ki so rezultat hitrega turbulentnega toka, nepovezanost sosednjih jam z zvezno vodno potjo. Zaradi aktivne tektonike je nivo morske gladine na Novi Zelandiji zelo spremenljiv, obdobja stabilnega vodnega nivoja so kratka, zato so jame tipa "Flank margin" na Novi Zelandiji manjše v primerjavi s tistimi v tektonsko stabilnejših okoljih, kot so Bahami, kjer nivo morske gladine uravnava zgolj glacioevstazija. Poudarjen vertikalni razvoj jam tipa "Flank margin” kaže na počasno in enakomerno tektonsko dvigovanje, razširitve in kanali v diskretnih horizontih, ki sekajo strukturo, pa kažejo na občasna (nezvezna) tektonska dogajanja. Jame tipa "Flank margin" nosijo neodvisen zapis o trajanju in hitrosti dvigovanja območij na Novi Zelandiji in tako nudijo možnost umeritve ostalih metod vrednotenja tektonskih dogodkov.

Ključne besede: jame tipa "Flank margin", Nova Zelandija, telogenetski karbonati, priobalne jame.

\footnotetext{
${ }^{1}$ Department of Geosciences, Mississippi State University, Mississippi State, MS 39762, USA Fax: (662) 3259423 , Email: mylroie@geosci.msstate.edu

${ }^{2}$ Department of Earth and Ocean Sciences, The University of Waikato, Private Bag 3105, Hamilton, New Zealand Fax: 0064-7-856 0115, Email: c.nelson@waikato.ac.nz
}

Received/Prejeto: 30.01.2008 


\section{INTRODUCTION}

It has been recognized for many years that the mixing of marine and fresh waters in coastal settings produces unique dissolutional features on both the surface (e.g. Folk et al., 1973; Taboroši et al., 2004) and in the subsurface (e.g. Back et al., 1986; Mylroie \& Carew, 1995) of carbonate rocks. One particular dissolutional feature, the flank margin cave, has been identified from coastal carbonates in a wide variety of settings, including the Bahamas (Mylroie \& Carew, 1990), Isla de Mona in Puerto Rico (Frank et al., 1998), Yucatan (Kelley et al., 2006), the Mariana Islands (Jenson et al., 2006), and Australia (White et al., 2007). A common factor in all of these locations is that the flank margin caves have developed in young carbonates that are diagenetically immature, or eogenetic (sensu Choquette \& Pray, 1970; see also Vacher \& Mylroie, 2002). Very little work has been done on flank margin caves in diagenetically mature, or telogenetic, carbonate rocks. One possible example is at Berry Head in Devon, UK (Proctor, 1988), where mixing dissolution in Paleozoic carbonates at a coastal setting may have resulted in cave development. The paucity of study of telogenetic mixing dissolution caves can be in part attributed to the relative scarcity of telogenetic carbonate rocks in coastal settings, and in part attributed to the inappropriate application of traditional continental conduit-flow stream cave dissolution models in coastal settings by earlier workers.

Eogenetic carbonate rocks are generally found close to their environment of deposition, so such carbonate rocks are usually found in coastal settings around the world. Carbonate islands in particular have offered a natural laboratory for study of mixing dissolution, as their rocks are commonly very young, and the islands are commonly very small. Such constraints on time and space limit the possible interpretations of the dissolution features found on and in those rocks. The eogenetic nature of the carbonate rock results in very high primary porosity, $30 \%$ being a common value (Vacher \& Mylroie, 2002). This setting facilitates diffuse flow in the carbonate aquifer, and allows mixing of fresh and marine waters over a broad area. As established for vadose and phreatic fresh water by Bögli (1980), and for saline and fresh water by Plummer (1975), mixing of waters that have saturated with respect to $\mathrm{CaCO}_{3}$ can result in more dissolution, if the waters became saturated at different initial conditions (Dreybrodt 2000). In carbonate islands with a fresh-water lens, the maximum dissolution occurs in the distal margin of the lens, under the flank of the enclosing landmass. The caves that form in this location are therefore called flank margin caves (Mylroie \& Carew, 1990; Neundorf et al., 2005, p. 241). The top of the fresh-water lens is a site of mixing of vadose fresh water and phreatic fresh water. The bottom of the lens is a site of marine water and fresh water mixing. Both mixing environments are capable of creating renewed dissolutional aggressivity, and at the lens margin they are superimposed upon each other to create an additive dissolutional effect. Further dissolutional potential is created by organic material that collects at the density contrasts provided by both the top and bottom of the lens. These organics can decay, releasing $\mathrm{CO}_{2}$ to promote further $\mathrm{CaCO}_{3}$ dissolution, and when present in abundance, these organics may lead to anoxic conditions and $\mathrm{H}_{2} \mathrm{~S}$-mediated dissolution (Bottrell et al., 1993). Finally, the thinning of the lens at its distal margin results in a decrease in lens cross-sectional area, and a consequent increase in water flow velocities (Raeisi \& Mylroie, 1995; Moore et al., 2007). Reactants flow in, and products flow out, faster at the distal margin than elsewhere in the lens. The ultimate outcome of all these geochemical and hydrologic parameters is the development of large dissolutional voids in a short amount of time at a specific location: the flank margin cave. Flank margin caves in eogenetic carbonate islands have a characteristic morphology of irregular chambers, maze areas, dead-end passages, and a horizontal dimension many times their vertical dimension (Fig. 1).

The initial work on flank margin caves was conducted in the Bahamas, where the host eogenetic carbonate rock was mid to late Quaternary eolianites. This rock is almost an ideal, simplistic carbonate material, as its deposition as a terrestrial limestone means it lacks marine cements, has never been buried or loaded, is well sorted, and is free of secondary structures such as faults, folds or joints. The first flank margin caves described were above modern sea level. In a tectonically-stable environment such as the Bahamas, elevation of the fresh-water lens above modern sea level in these eolianites could only have been accomplished by glacioeustasy during interglacials. The rate of Bahamian platform subsidence is 1 to $2 \mathrm{~m}$ per $100 \mathrm{ka}$ (Carew \& Mylroie, 1995; McNeill, 2005). In the Atlantic Basin, only the last interglacial or Marine Isotope Stage (MIS) 5e, from about 131 to $119 \mathrm{ka}$ (Chen et al., 1991), could have placed sea level, and the fresh-water lens supported by that sea level, at the $6 \mathrm{~m}$ elevation required by existing flank margin caves. Earlier interglacials were either not high enough (MIS 7), or too far back in time, given isostatic subsidence rates (MIS 9 or 11), to have created the necessary elevated fresh-water lens position and caves as observed today (Carew \& Mylroie, 1995). The time window in which to form flank margin caves, which commonly have volumes in excess of $25,000 \mathrm{~m}^{3}$, was only the 12,000 years dura- 


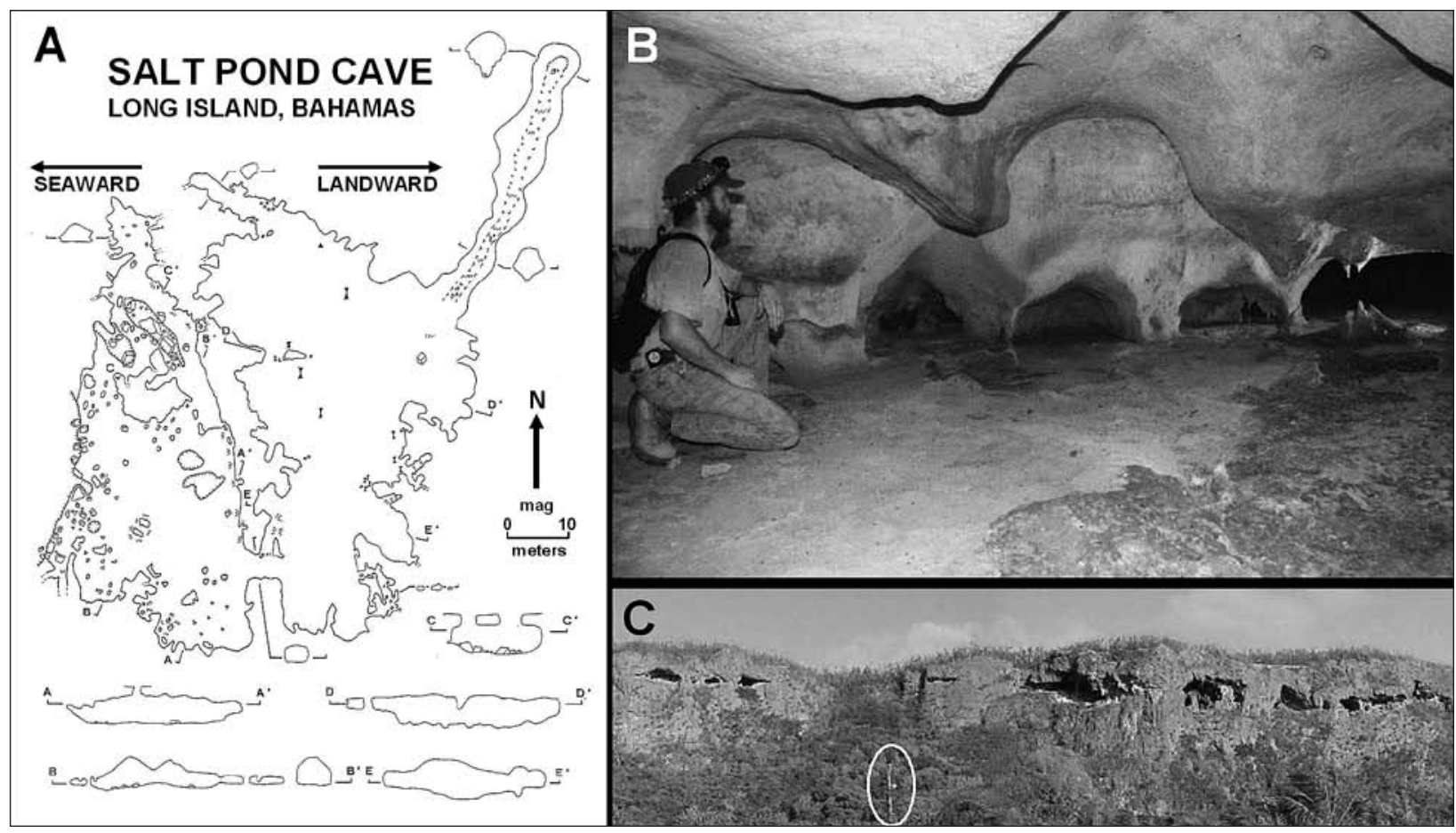

Fig. 1: A - Map of Salt Pond Cave on Long Island, Bahamas, a typical Bahamian flank margin cave. Note the flattened, globular nature of the cave chambers, their irregular walls, and maze-like configuration. A note on map symbols for cave maps in this paper: rectilinear blocks represent breakdown (collapse material); lines with hachures indicate a vertical surface with hachures on the down side; three diverging lines indicate a slope, downward in the direction of divergence; black triangles indicate stalactites (apex down) and stalagmites (apex up); cross sections designated by labeled lines (A to A', etc.), or by lines extending from, but not touching, cave walls. B - Flank margin cave passage in Cueva del Agua Sardinera, Isla de Mona, Puerto Rico. The cave passage is wider than it is high, and has wall cusps, bedrock pillars, and dissolutional morphology consistent with low-velocity, phreatic-flow conditions such as exist in flank margin caves. C - Flank margin caves exposed in the Suicide Cliffs, Tinian, Commonwealth of the Northern Mariana Islands. Cliff retreat has exposed a series of flank margin caves at a single horizon, which represents a stable position of the fresh-water lens prior to tectonic uplift. Upper part of telephone pole in foreground (circled) for scale.

tion of the last interglacial. During the last interglacial, when sea level was up to $6 \mathrm{~m}$ higher than at present in the Bahamas, the land area was much smaller than today, and consisted mostly of eolian ridges acting as small, independent islands. Flank margin caves in the Bahamas therefore developed under severe constraints of time and space: in 12,000 years in fresh-water lenses of areal extent as small as a few hectares.

Research into flank margin cave development subsequently expanded into other carbonate island settings where the geology was more complex, such as Isla de Mona in Puerto Rico (Frank et al., 1998) and the Mariana Islands (Jenson et al., 2006). In these cases the carbonate units, while older than in the Bahamas, were still eogenetic, but the structural situation was more complex. Tectonics overprinted glacioeustasy, and faults and gentle folds were present, along with abundant jointing. The carbonate rocks were marine, diagenetically variable, and in the Marianas, juxtaposed with non-carbonate rocks. Despite these additional complications, the general pattern of flank margin cave development as seen in the Bahamas persisted. Passage elongation parallel to major joints was one significant difference from the Bahamian condition, as joints provided preferential flow paths in the freshwater lens, and therefore mixing environments, in these porous and permeable eogenetic carbonate rocks.

The question of interest then became the outcome of mixing zone dissolution in dense, diagenetically mature, telogenetic carbonate rocks. Such rocks have little or no matrix permeability. In interior continental settings such rocks create the classic fluvial karst with high-velocity, turbulent conduit flow; the epigenic caves of Palmer (1991). The permeability is almost entirely along bedding planes, joints, and faults, and conduits preferentially follow these fundamental flow pathways. It was reasonable to consider that flow in a fresh-water lens in telogenetic carbonate rocks in a coastal setting would be similarly constrained to bedding planes, joints, and faults. To test the reaction of mature telogenetic carbonate rocks to mixing dissolution in the distal margin of a fresh-water lens required a location where these rocks would be present, preferably in many varied settings. 


\section{COASTAL CARBONATES IN NEW ZEALAND}

New Zealand, both North and South Island, contain a variety of limestones cropping out in coastal locations in a multitude of settings. While these rocks are geologically young, Cenozoic in age, they are associated with a very active tectonic environment and have been subjected to a variety of diagenetic conditions, leading to a variety of diagenetic maturities between eogenetic and mainly telogenetic (Nelson, 1978; Nelson et al., 1988; Caron et al., 2006). The caves described in this paper are entirely from telogenetic carbonate rocks. The active tectonic setting also means that both glacioeustasy and tectonic movement have controlled the placement of sea level with respect to the coastal carbonate outcrops. The key factor in this regard is the duration of a stable sea-level position, which in turn controls the time stability of the fresh-water lens. Data from the Bahamas (Mylroie \& Mylroie, 2007a) and from Isla de Mona (Frank et al., 1998) indicate that a constantly moving sea level, and a constantly moving fresh-water lens, allow too little time for macroscopic dissolution to develop flank margin caves. On the other hand, the Bahamian data also show that even limited lens-stability time can create observable flank margin caves. The tectonic setting of New Zealand offers an opportunity to determine what minimum sea-level stability time would be necessary for a fresh-water lens to produce a macroscopic flank margin cave by mixingzone dissolution.

\section{METHODOLOGY}

The development of flank margin caves, at the distal margin of the fresh-water lens and under the flank of the enclosing landmass, places their site of origin in a coastal environment. These dissolution voids develop mere meters from the shoreline and so they are vulnerable to breaching and destruction by marine erosional processes (Walker, 2006). In the stable Bahamas, sea level today is $6 \mathrm{~m}$ below that of the last interglacial when the flank margin caves formed. In most cases, these flank margin caves are separated today by a considerable lateral distance from modern wave action. In some cases, however, modern wave erosion is cliffing some eolianite ridges and breaching the flank margin caves contained therein. In rugged and steep-sloping carbonate outcrops, as exist in much of coastal New Zealand, past and current glacioeustatic sea-level highstands place wave energy in approximately the same position. Flank margin caves are therefore vulnerable to erosional removal, and the search for flank margin caves must take into account their survivability at any given coastal location. It is also important that sea caves, produced by mechanical erosive action of waves (Fig. 2), can be differentiated from true flank margin caves produced by dissolution and subsequently breached by wave action. In the Bahamas (Waterstrat, 2007), and in Puerto Rico (Lace, 2008), criteria for doing such a differentiation have recently been established. To overcome survivability issues for flank margin caves, protected coastal locations, such as harbours and inlets, were given priority for examination. Such locations would have a coastal fresh-water lens, but the rocks would be protected from the high-energy wave attack of the open coast that might remove existing flank margin caves (Mylroie \& Mylroie, 2007b).

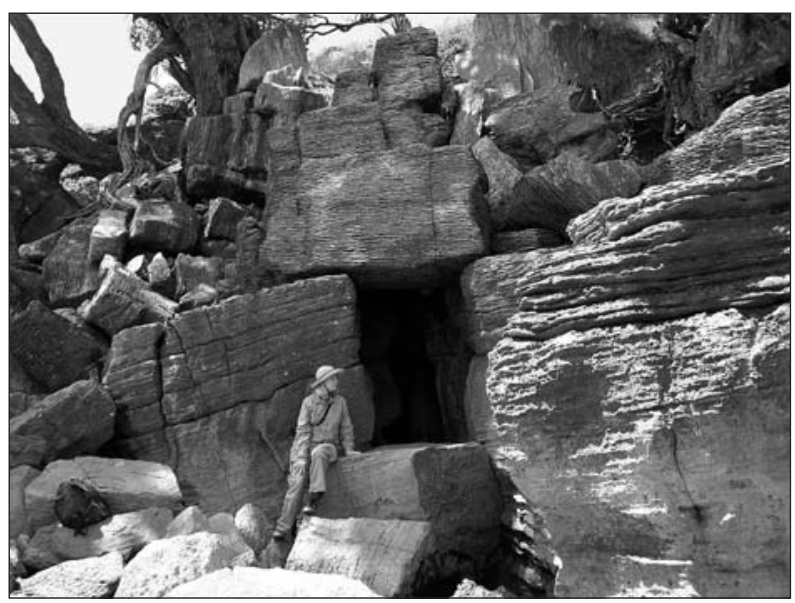

Fig. 2: Cave at Waipu Cove, North Island, New Zealand, in flaggy Oligocene Whangarei Limestone. This small cave has been created by wave energy moving a block of limestone, separated by joints, laterally along bedding planes, to the left in the figure. While minor dissolution may have enlarged the bedding planes and joints, making the block vulnerable to wave energy, production of the large void was a mechanical process.

At each location, coastal outcrops were searched for phreatic dissolutional voids. These were surveyed with a fiberglass tape, Suunto compass, and Suunto inclinometer, following the guidelines of Dasher (1994). Each survey was linked to the high tide mark. Each karst feature 
was photo-documented. When karst features were in close proximity, they were linked by a surface survey to establish relative position within $10 \mathrm{~cm}$. The survey data were processed to create a plot of the survey stations, around which the cave walls were drawn using sketch notes from the field site.

The caves were examined for evidence of phreatic dissolution: bedrock pendants and columns, curvilinear bedrock surfaces, bell holes (ceiling pockets), and wall and ceiling cusps. The caves were also examined for evidence that would indicate a high-velocity, turbulent-flow conduit origin: turbulent flow wall markings such as scallops, vadose canyons, and stream-laid clastic sediments. The continuity of the cave chambers was also examined, to see if they were isolated bedrock pockets, or truncated portions of larger, integrated conduit caves. Caves in coastal settings with abundant phreatic dissolutional features, but no evidence of high-velocity turbulent stream flow, and which are present as isolated and unconnected chambers, would be interpreted as flank margin caves.

The presence of speleothems, especially in caves now open and well-ventilated, suggests that the caves were once sealed chambers, which allowed speleothem growth in humid (non-evaporative) conditions by $\mathrm{CO}_{2}$ diffusion. The caves were later breached to create an entrance and subsequent ventilation. Dense, well-crystallized calcite speleothems are an excellent indicator of a sealed cave environment (Taborosi et al., 2006). Speleothem criteria allow sea caves, which form in an always-open condition and do not precipitate dense calcite speleothems, to be differentiated from breached flank margin caves. When a flank margin cave is breached and undergoes wave attack, the cave can be stripped of its speleothems and its delicate phreatic dissolutional morphology. In such cases, differentiation of the two cave types is difficult.

\section{RESULTS}

\section{NORTH ISLAND}

Coastal limestone outcrops were examined in three different settings on North Island: Raglan and Kawhia Harbours on the west coast, the Napier area on the southeast coast, and Waipu Cove on the northeast coast (Fig. 3).

Raglan Harbour - The entrance to Raglan Harbour is $40 \mathrm{~km}$ west of the city of Hamilton (Fig. 3). The harbour extends eastward for approximately $10 \mathrm{~km}$. Raglan township is on the south shore of the entrance channel to the harbour, and directly across the channel to the north is Marotaka Point, where a thin band of Oligocene Raglan Limestone is exposed in a coastal setting. The Raglan Limestone is a telogenetic, light grey, flaggy bioclastic limestone with about $80 \% \mathrm{CaCO}_{3}$. The local exposed thickness is between 10 and $15 \mathrm{~m}$.

The coastal outcrops are a series of blocks and towers of limestone, that grade inland into solid terrain cut by deep, dissolutionally-enlarged joints, before the limestone disappears under overlying units (Fig. 4). The tidal range is up to about $3 \mathrm{~m}$, and the coastal outcrops are cyclicly inundated and drained of tidal water. The coastal outcrops show a distinct intertidal notch. The deep dissolutional fissures, which are shallow and choked with soil and debris inland, become progressively deeper and more open towards the coast. Some of the enhanced expression of these features is the result of sapping by tidal waters, such that the infill material has been removed allowing the full depth of these epikarst features to be observed. However, the fissures widen dramatically in the coastal zone, especially in and slightly above the intertidal zone.
This widening has been sufficient enough to isolate individual blocks of limestone as towers and pedestals. Some of these towers have toppled (Fig. 4A). The dissolutional sculpturing of the limestone has changed from an epikarst, vadose-flow environment inland to a coastal, cyclic marine-erosion environment at the shoreline.

Subsoil epikarst dissolution, where soil water and descending vadose water is held against the rock like water in a sponge, creates smooth, curvilinear dissolutional surfaces that can have a similar appearance to phreatic dissolutional surfaces. These dissolutional surfaces extend from the top, inland portion of the limestone outcrop to the coastal outcrops in the intertidal zone. The epikarst subsoil dissolutional surfaces first merge with, and then are replaced by, marine intertidal erosion surfaces, which are also smooth and curvilinear (Fig. 4B). Numerous oval, tubular passages up to $1 \mathrm{~m}$ in diameter and larger, are present in the limestone within the intertidal zone, commonly with oysters attached to the entire tube wall (Fig. 4C and 4D). Some of these passages cut through a tower or outcrop, some end in sediment fill, and some end in a solid bedrock wall. All follow a joint or bedding plane or both, but the oval passage shape can make the initiating flow path obscure. These caves are short in length, rarely exceeding $10 \mathrm{~m}$ in linear dimension. The caves are consistent with a flank margin origin.

Kawhia Harbour - Kawhia Harbour is also on the west-central coast of North Island, about $25 \mathrm{~km}$ south of Raglan Harbour (Fig. 3). It extends inland 12 km, and along the southeast shore of the harbour are coastal out- 


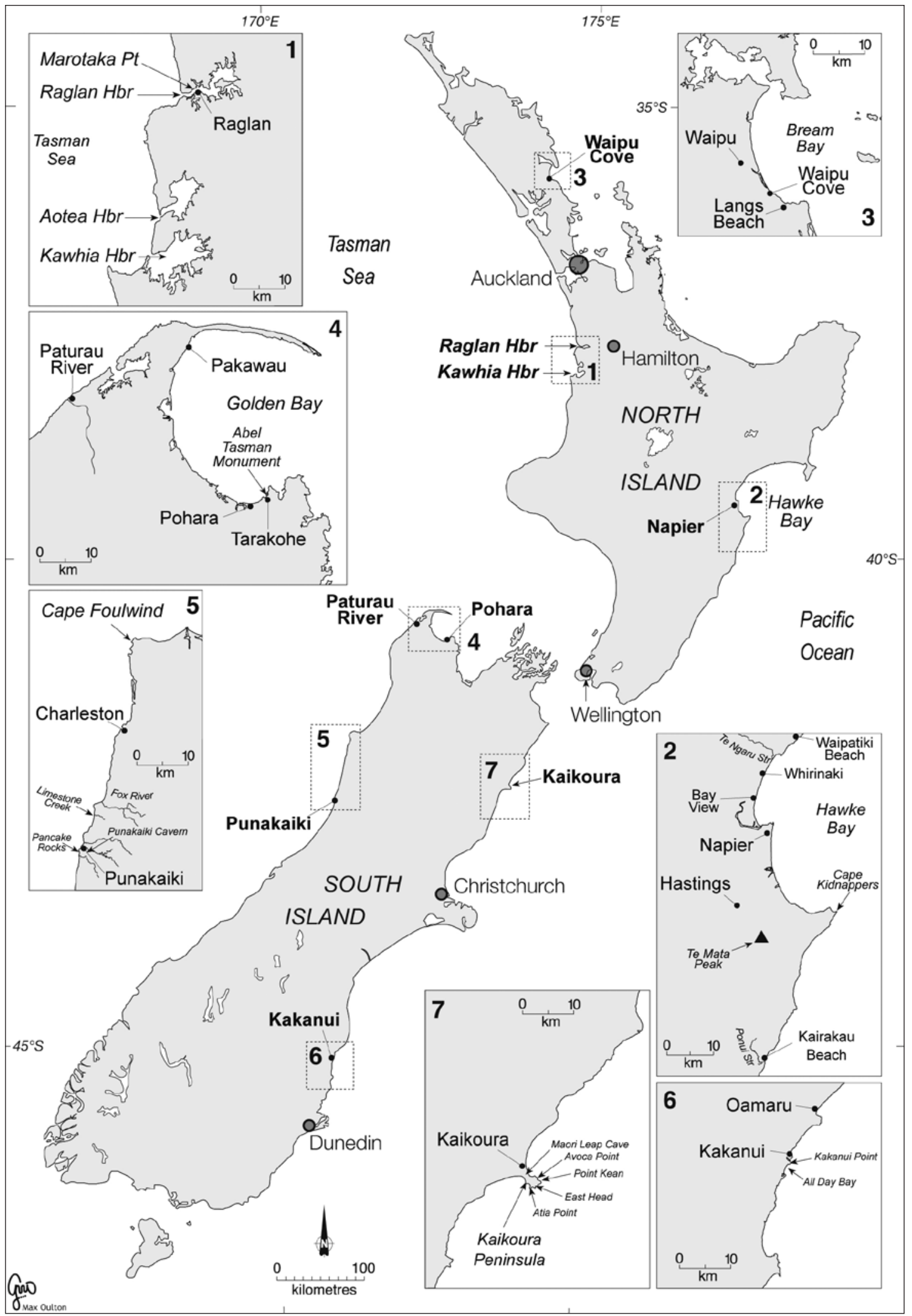

Fig. 3: Map of North and South Island, New Zealand, showing limestone outcrop locations investigated for this study. The inset maps are numbered in order of the discussion of those sites in the text. 


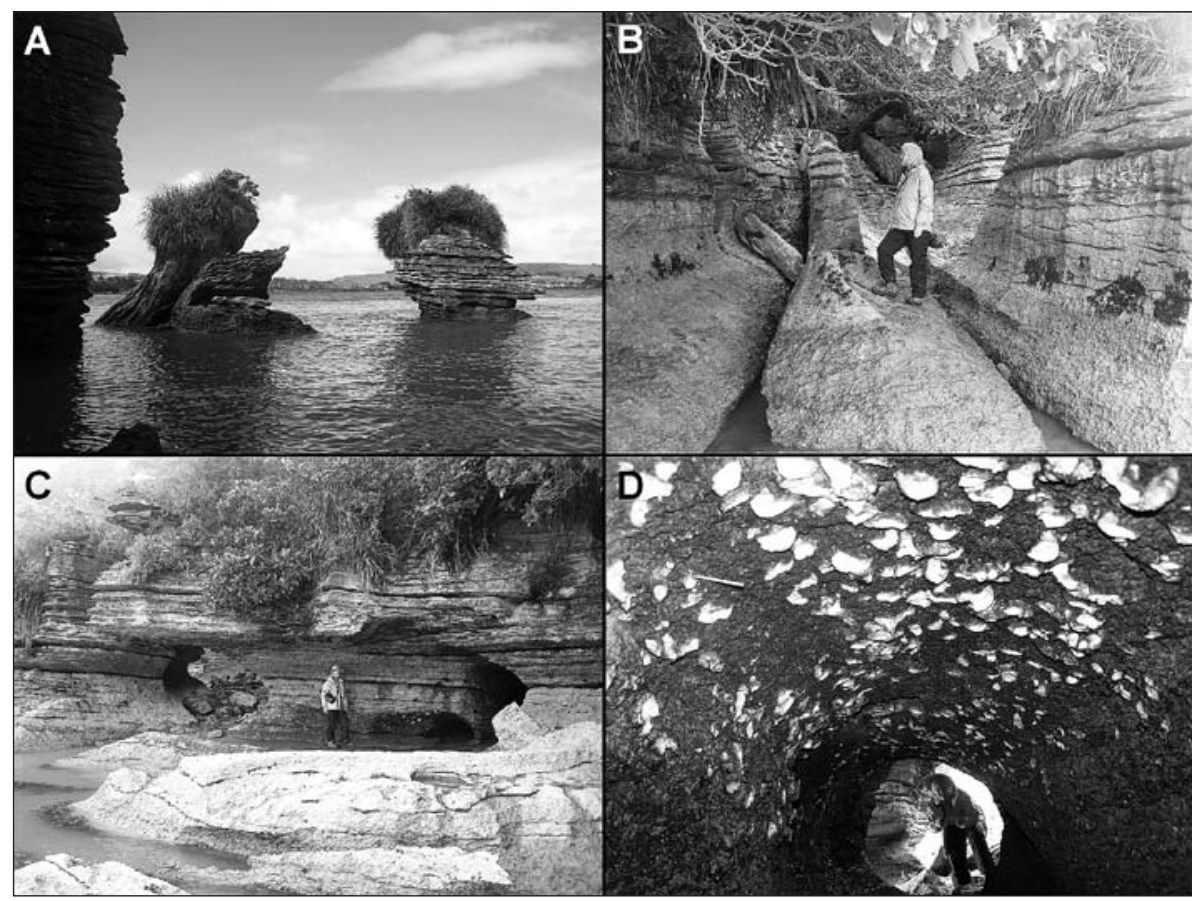

Fig. 4: Raglan Harbour (Late Oligocene Raglan Limestone). A - Isolated towers of Raglan Limestone, Marotaka Point. Note that the left tower has toppled. The right tower is $7 \mathrm{~m}$ high. $B$ - Joints descending from the epikarst into the intertidal zone, where marine erosion has notched the limestone. C - Coastal outcrop showing tubular passages and coastal notching. D - Limestone tube approximately $1 \mathrm{~m}$ in diameter, covered with scars of modern (not fossil) oysters. this site: outcrops on the current coastal area and isolated coastal hills reaching an elevation of up to $40 \mathrm{~m}$ (Fig. 5).

The coastal outcrops show the enlarged epikarst joints that were common at Raglan Harbour, with some coastal notching. A series of small phreatic tubes, averaging 10 to $30 \mathrm{~cm}$ in diameter, are present at a common horizon slightly above the high tide mark along the western margin of the outcrop (Fig. 5A). These tubes may represent mixing dissolution prior to recent uplift on this tectonically-active coast (Pillans, 1986). Larger tubes, in the 1 to $3 \mathrm{~m}$ diameter range, are present in several locations (Fig. 5B, 5C and 5D).

The two hills have a series of small caves and phreatic tubes. On the lower hill, the tubes almost entirely encircle the hill at $15 \mathrm{~m}$ elevacrops of telogenetic Oligocene Orahiri Limestone, a san$\mathrm{dy}$, bioclastic limestone with oysters. The outcrop here is at least $30 \mathrm{~m}$ thick. There are two main areas of study at tion (Fig. 5B and 5C, Fig. 6A and 6B). On the higher hill, at approximately $25 \mathrm{~m}$ elevation, a series of small phreatic caves are found in a continuous line on one side of

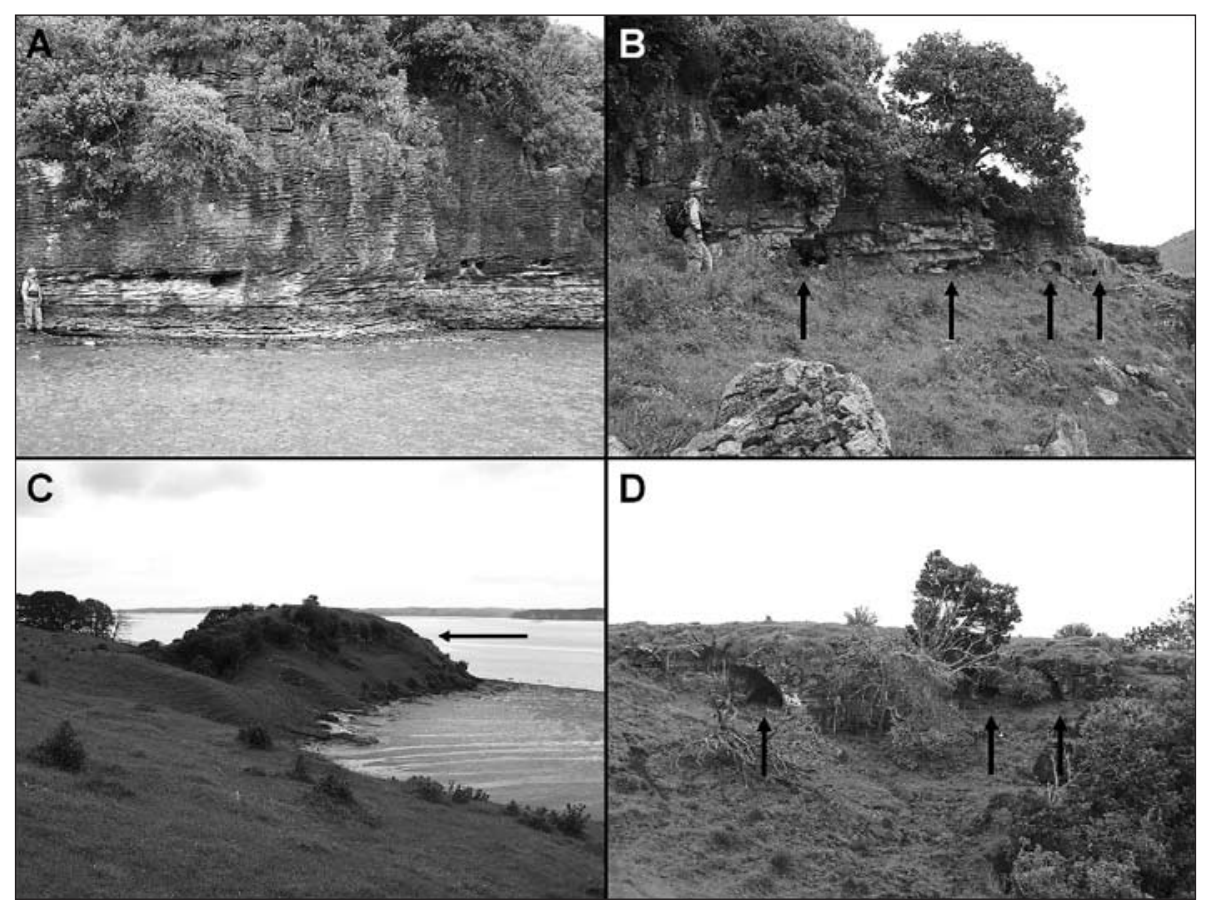

Fig. 5: Kawhia Harbour (Late Oligocene Orahiri Limestone). A - Southeastern shore of Kawhia Harbour, with a line of dissolution tubes trending continuously along a coastal outcrop of Orahari Limestone at just above the high tide mark, on the left side of the hill shown in (5C). Person at left for scale. $B$ - Line of dissolution tubes, marked by black arrows, at an elevation of $15 \mathrm{~m}$ above sea level. This face is on the far side of the hill shown in (5C). C - Isolated hill of Orahari Limestone. All sides of this hill have dissolution features at about $15 \mathrm{~m}$ above sea level (arrow), as described in the text. D - Large dissolution tubes in the side of a hill (the hill from which the Fig. 5C photograph was taken) at 25 m elevation, marked by black arrows. 


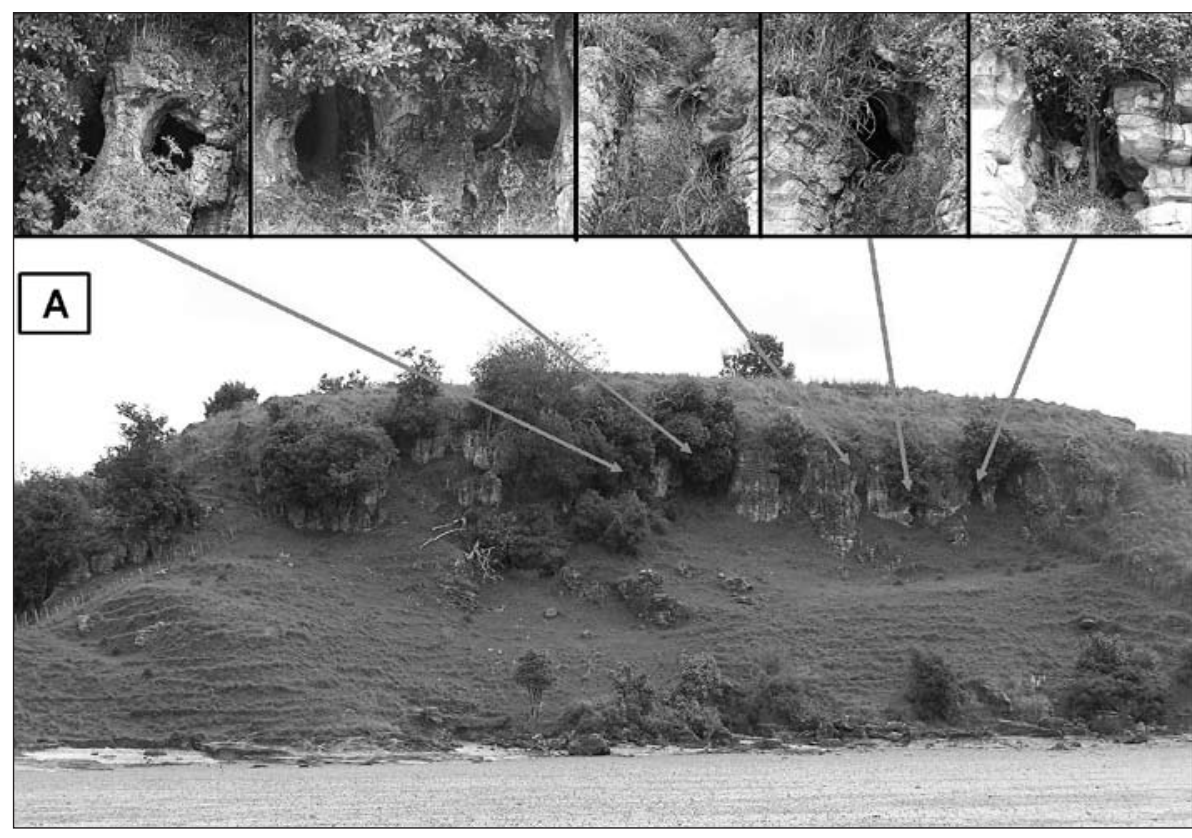

Fig. 6: Kawhia Harbour (Late Oligocene Orahiri Limestone). A - View of tube segments visible on the face of the cliff highlighted by the black arrow in Fig. 5C. B - Map of the tube segments visible in Fig. 6 A.

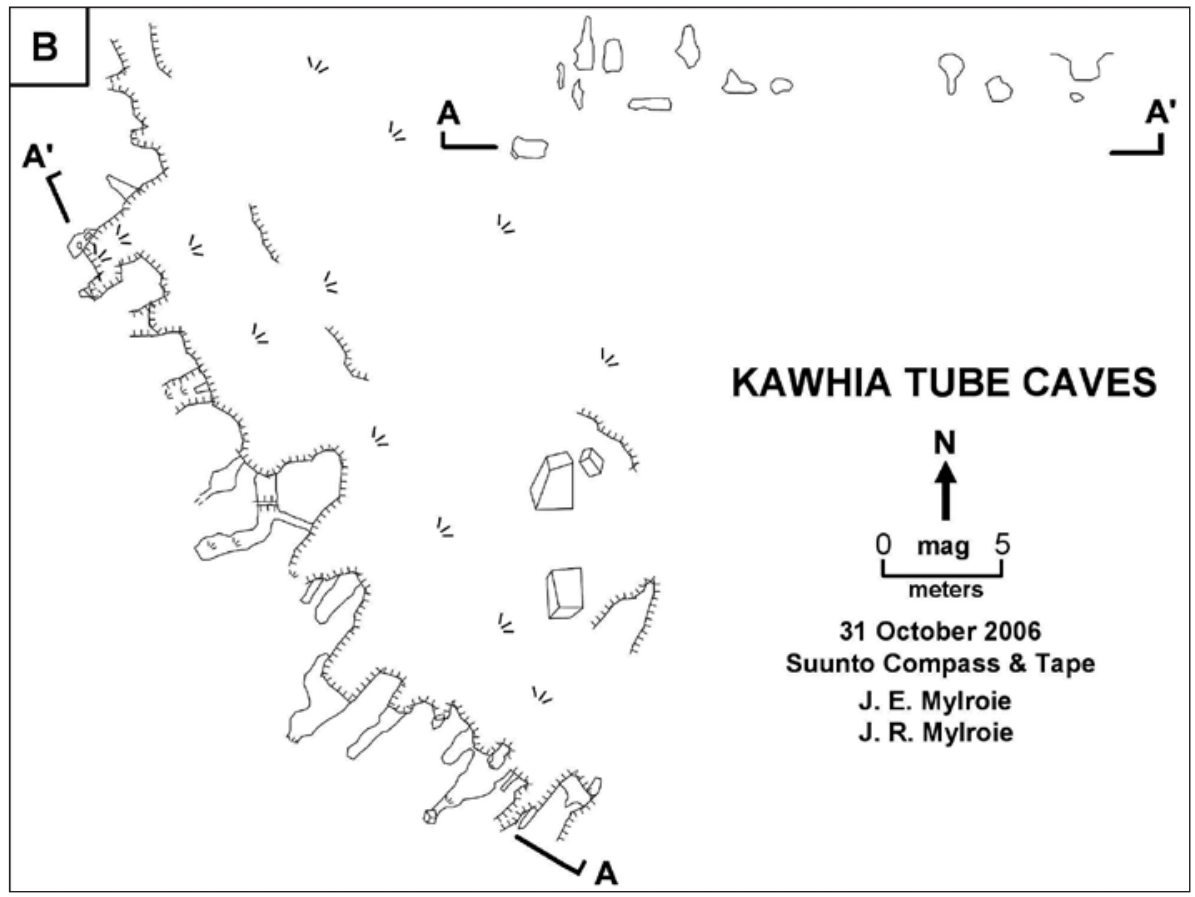

along a horizontal datum suggests a base-level control, which in this setting could be a pre-uplift sea level and concurrent mixed-water dissolution.

One $15 \mathrm{~m}$ long tube network is associated with Kawhia Oyster Tube Cave, a very large cave chamber open to the seaward side (Fig 7 and Fig 8). Given the low wave energy conditions of the harbour interior, and the lack of other major wave-erosion features along this coast, this cave may well be a breached flank margin cave.

Napier - North of Napier (Fig. 3), at the southern end of Hawke Bay, are coastal outcrops of coarse-grained bioclastic Pliocene limestone assigned to various formations (Nelson et al., 2003) stretching from Waipatiki Beach south to Bay View, just north of Napier. Coastal reconnaissance failed to find any dissolutional caves except at a small coastal outcrop of Waipatiki Limestone to the north of the Whirinaki community and just south of Te Ngaru Stream. In this small, low hill, the seaward face has been cliffed by wave action, and a series of small caves revealed (Fig. 9A). The caves are a collection of small tubes, small chambers, and vertical fissures (Fig. 9B and 9C). The top of the outcrop is capped by a siliciclastic mudstone unit, which isolates the carbonate

the hill (Fig. 5D). Some of the caves penetrate the hillside for a distance of 8 to $10 \mathrm{~m}$ as irregular chambers up to 2 $\mathrm{m}$ high and $4 \mathrm{~m}$ wide (Fig. 7D), while others are short tubes only a few meters long. Many of the smaller tubes are associated with dissolutionally-widened joints, and have an appearance similar to tubes found in typical epikarst situations. However, the alignment of these tubes unit below from any epikarst development. The caves all show phreatic morphology, and are somewhat regularly spaced along the cliffed hillside (Fig. 10). They are distributed over a vertical range of $4 \mathrm{~m}$. The Napier area is famous for tectonic activity, and in 1931, a magnitude 7.8 earthquake resulted in coastal uplift in the vicinity of Napier of up to $2.4 \mathrm{~m}$ (Hull, 1990). It is quite likely 


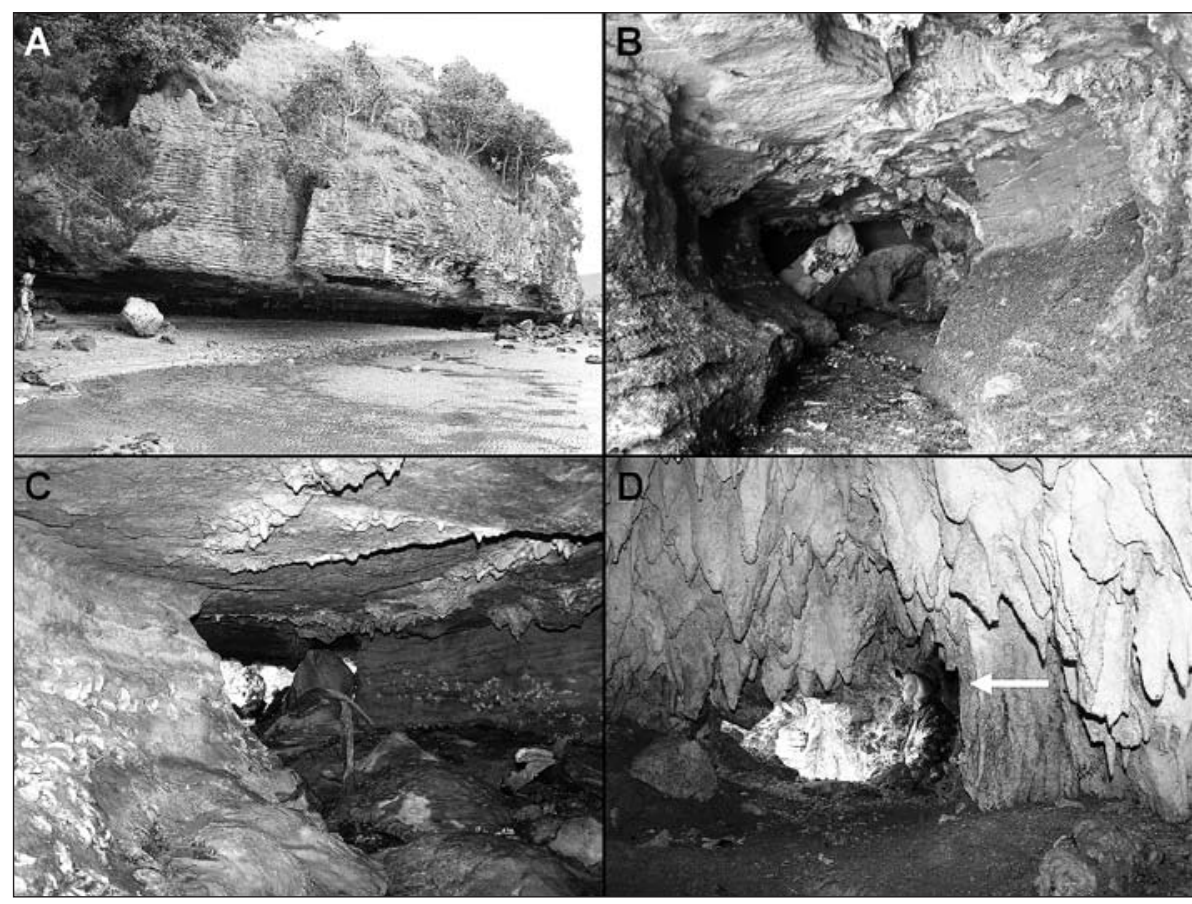

Fig. 7: Kawhia Harbour (Late Oligocene Orahiri Limestone). A - Large cave chamber with its outer wall breached. At the back end of this chamber, passages shown in Fig. $7 B$ and 7C lead through the outcrop and back to the coast. Person at left for scale. B - Tubular passage leading from the coast into the cliff shown at the far end of Fig. 7A. Person for scale; note the old flowstone on ceiling and floor. C - Passage into the large breached chamber. Person in distance for scale; note modern oyster scars on cave walls and old flowstone. D-Abundant speleothems in a small cave at the $15 \mathrm{~m}$ level of the hill shown in Fig. 5C. Person seated against right wall for scale, white arrow points to person's head.

that the flank margin caves seen at Whirinaki are Holocene in age.

In Napier itself, coastal cliff outcrops up to $30 \mathrm{~m}$ high of the Late Pliocene Scinde Island Limestone front the harbour, but contain no significant flank margin caves. Numerous small subaerial weathering pockets, which appear like tafoni, mottle the outcrop surface. Differentiation of tafoni from flank margin caves on carbonate cliffs has been established from work in the Bahamas (Owen, 2007).

South of Napier, and south of Hastings and Cape Kidnappers, the Early Pliocene Kairakau limestone crops out north along the coast for several kilometers from Kairakau Beach (Fig. 3). No dissolution caves were found on the seaward facing cliffs of the unit. A stream valley 1.5 $\mathrm{km}$ north of Kairakau Beach, flowing west to east, bisects the coastal cliff, creating protected limestone cliffs on its north and south banks. Despite a detailed search, no dissolution caves were found in this locality. The site could be considered ideal, as at past higher sea levels it would have contained marine water, but its protected setting would have prevented significant cliff retreat and flank margin cave removal. The absence of flank margin caves here is unexplained. A small pit cave was noted in sec- tion high on an inland cliff face, along the south bank of the Ponui Stream that flows to the hamlet of Kairakau Beach, just west of that town.

Between Kairakau Beach and Hastings, and inland 15 $\mathrm{km}$, is $399 \mathrm{~m}$ high Te Mata Peak, formed on the Middle Pliocene Awapapa Limestone (Fig. 3). While no longer in a coastal setting, the dramatic east-facing scarp contains several large phreatic pockets that may be relict flank margin caves (Fig. 11). A smaller pair of these phreatic pockets can be reached at the base of a small cliff that is above the road just north of the main Te Mata summit. These pockets are rounded cavities in the limestone, with a morphology typical of small flank margin caves (Fig. 11D). The presence of such relict features is a measure of the degree of hillside retreat. In this case, retreat would be relatively minor as the caves are still present. Rapid uplift would explain their survival at such a high elevation. The location of the caves along a single, but not level, horizon is evidence that flank margin cave remnants can survive uplift and tectonic rotation (Fig. 11C).

Waipu Cove - Waipu Cove is $30 \mathrm{~km}$ southeast of Whangarei (Fig. 3). From Waipu Cove south to Langs Beach, telogenetic Oligocene Whangarei Limestone crops out in a coastal setting. At least 15 vertical meters of limestone are exposed. The outcrop is at the southern end of Bream Bay, a relatively exposed situation as regards wave energy (Fig. 2). The limestone rests unconformably on Permo-Triassic basement greywackes and argillites. This contact is above sea level on the Waipu Cove end of the outcrop. As previously described at Raglan Harbour, large vertical fissures cut through the sequence, initiating inland and upwards as epikarst features, that grade downward and seaward in the coastal notching zone to create isolated stacks and towers (Fig. 12A). The walls of these enlarged fissures contain numerous phreatic tubes and small caves (Fig. 12B through Fig. 12E). In fissures slightly inland from the active wave base, delicate dissolutional morphology is visible, indicating that wave ener- 


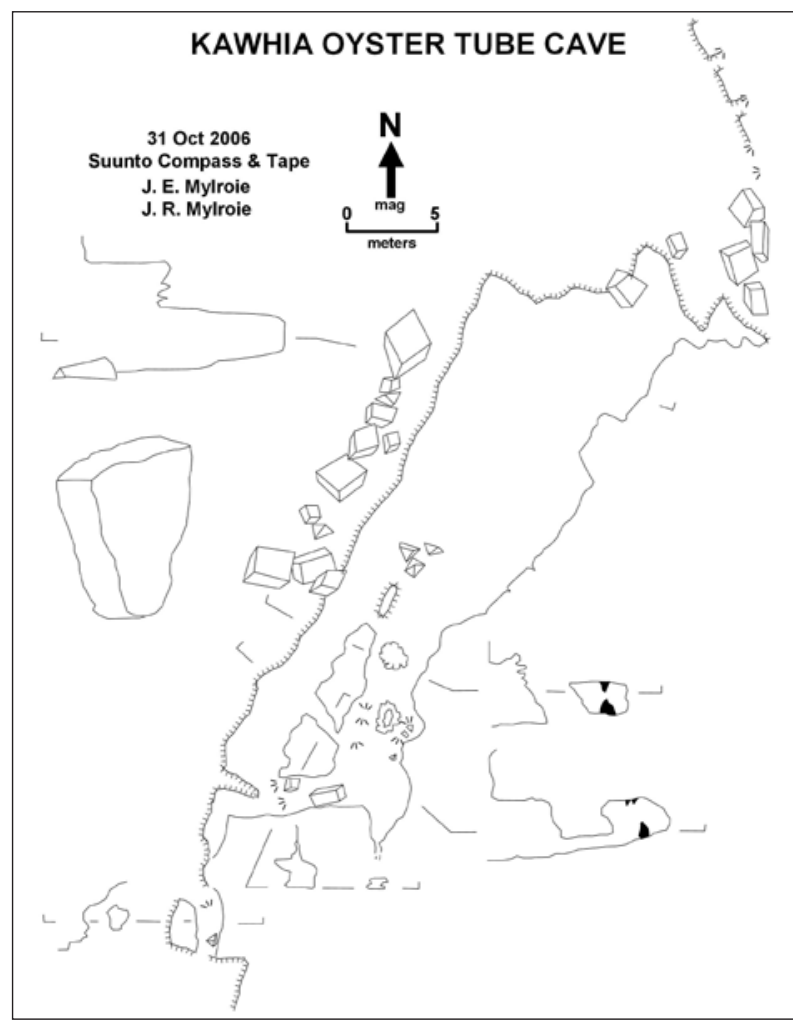

Fig. 8: Map of cave shown in Fig. $7 A, 7 B$ and $7 C$. The cave is an isolated chamber. gy alone is not responsible for much of the observed cave morphology. Phreatic tubes and enlarged fissures penetrate for more than $10 \mathrm{~m}$ in numerous locations, with lateral enlargements that hold a horizontal trend across the dipping beds (Fig. 12D). Followed into the outcrop, these dissolutional passages undulate in a classic phreatic pattern (Fig. 12C), but contain no indicators of high-velocity turbulent flow.

\section{SOUTH ISLAND}

Coastal limestone outcrops were examined at five different locations in South Island: Pohara on the north coast, Paturau River on the northwest coast, Punakaiki on the west-central coast, Kakanui on the east-central coast, and Kaikoura on the northeast coast (Fig. 3).

Pohara - Telogenetic Oligocene Takaka Limestone crops out in the vicinity of Pohara and Tarakohe on the southeast shore of Golden Bay (Fig. 3). The coastline in this area is fairly rugged, and wave energies are high. At this locality the Takaka Limestone overlies the mechnically-weak Eocene Brunner Coal Measures and as a result is quickly undermined by wave action in coastal areas to form a limestone mega-rubble embankment at sea level (Fig. 13A). Much of the coastal outcrop is thus obscured, but at the Abel Tasman monument just north of Tarakohe, a large, cliffed bluff of Takaka Limestone is preserved west and above the road. This outcrop has a series of dissolu-

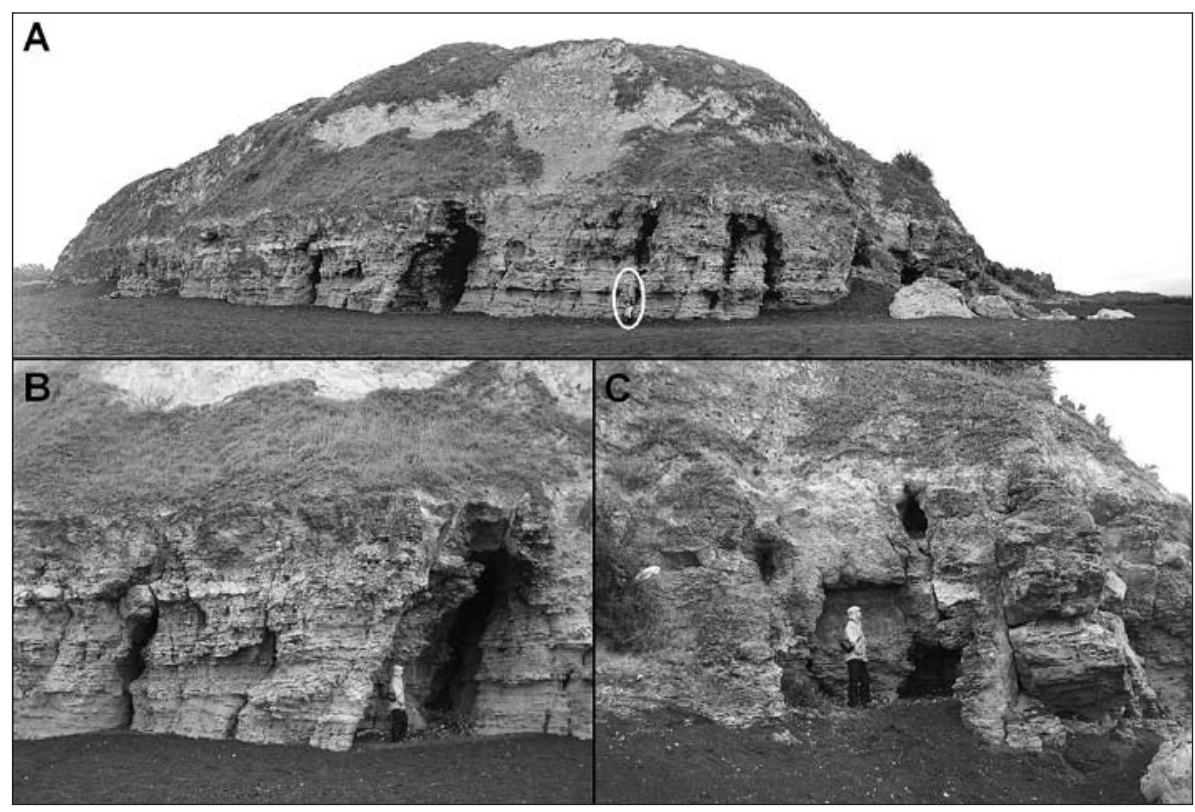

Fig. 9: Napier district (Late Pliocene Waipatiki Limestone). A - The small beachside hill north of Whirinaki contains a series of short flank margin caves, which are exposed on the seaward side of the hill, where wave action has breached into them. Person standing at cliff base in right center, circled, for scale. B - Some of the caves at Whirinaki. Note that the limestone is covered by siliciclastic mudstone, so no epikarst development has occurred. $C$ - Isolated tubes and chambers at Whirinaki. The vertical extension of these caves, as seen in Fig. 9B, and the separation into stacked tubes, as seen in Fig. 9C, are evidence of rapid uplift. tional voids that cut across the existing rock structure (Fig. 13B). These voids are up to 2 to $3 \mathrm{~m}$ high and wide, and extend inward for 3 to $4 \mathrm{~m}$ (Fig. 13C). They are regularly spaced along the outcrop and their pattern and morphology are consistent with mixedwater dissolution. Northwest $80 \mathrm{~m}$ along the road and the exposed cliff, in a road cut on the west side of the road, is a single chamber cave at the same elevation as those to the south. The cave is $7.5 \mathrm{~m}$ long and $4 \mathrm{~m}$ wide, with a vertical range of $3 \mathrm{~m}$, trending southwest (Fig. 13D). It contains much collapse material, and secondary calcite precipitates (speleothems), so the original dissolution surfaces of the cave are obscured, and its mode of speleogenesis is not obvious. 


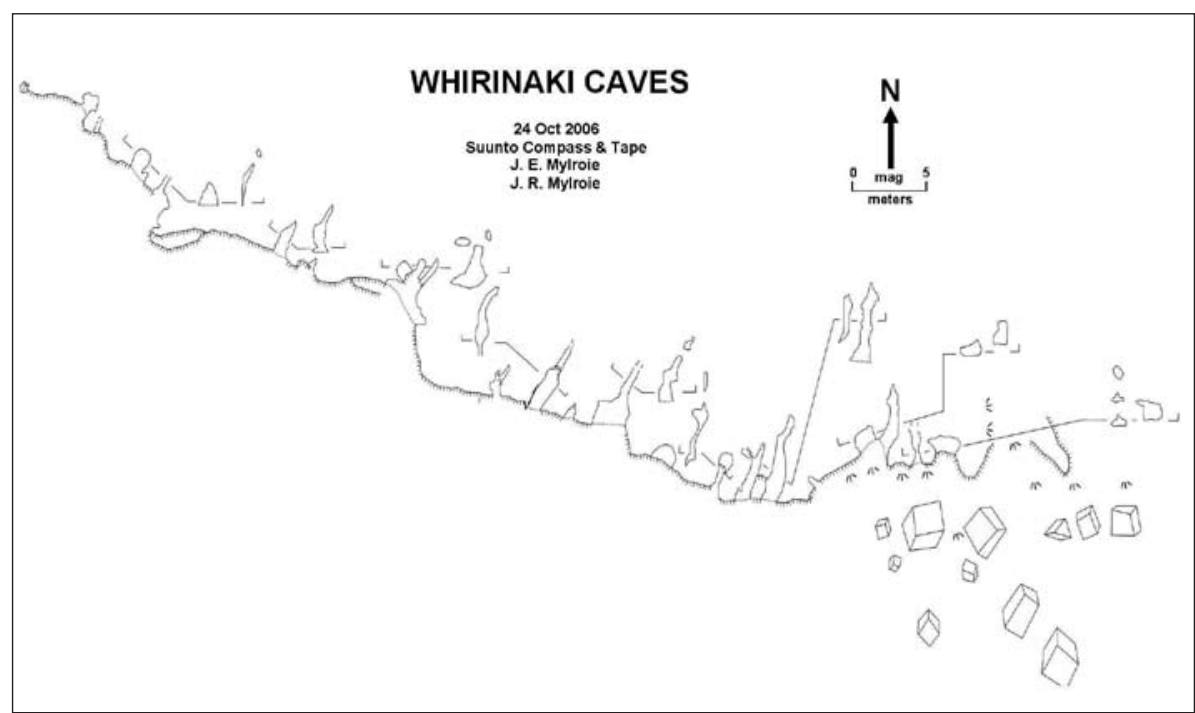

Fig. 10: Map of the Whirinaki caves. The caves open southward on to beach seen in the foreground of Fig. 9.

The cliffs west of the Abel Tasman monument contain a number of isolated phreatic chambers that have been breached by cliff retreat, to reveal the calcite spe-

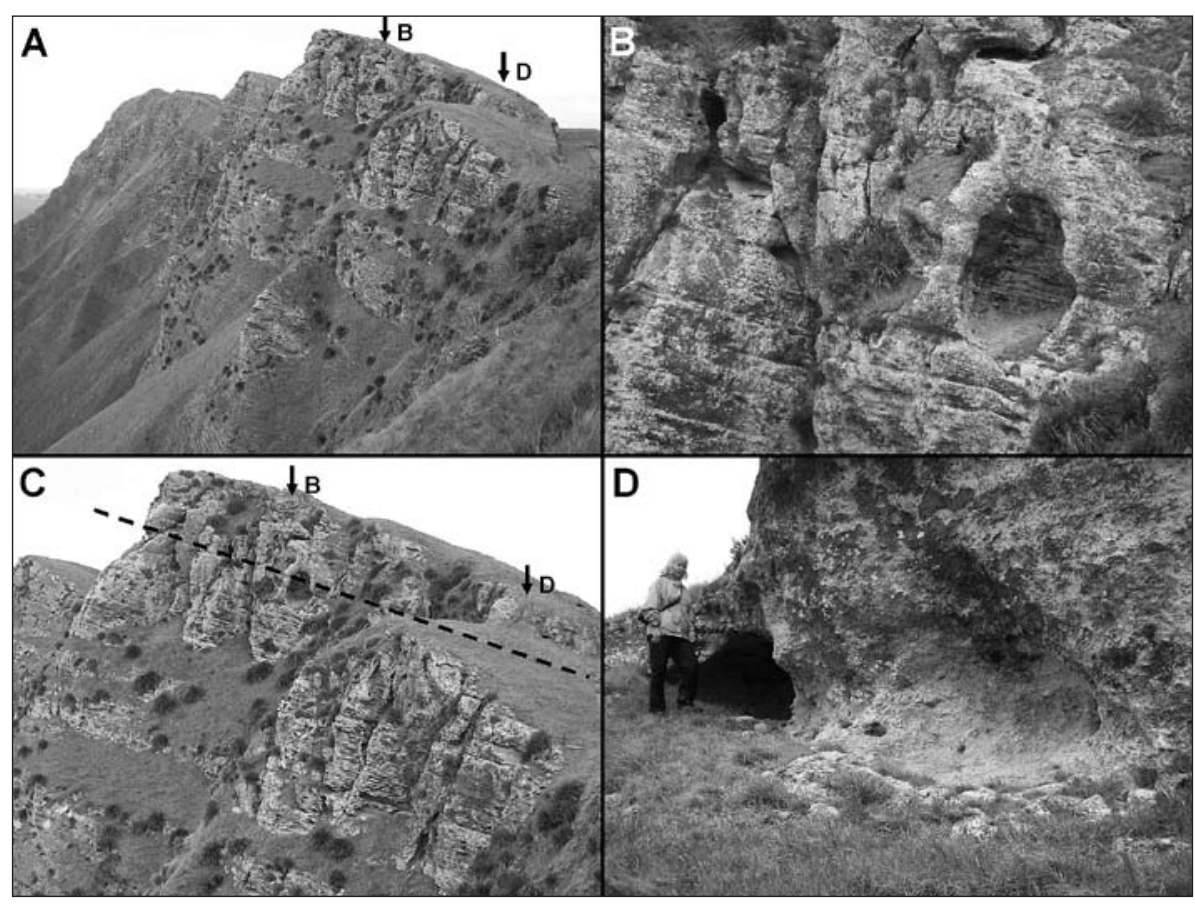

Fig. 11: Napier district (Middle Pliocene Awapapa Limestone). A -Te Mata Peak formed in wellbedded Awapapa Limestone, here about $120 \mathrm{~m}$ thick. Arrows marked B and D identify the locations of the features shown in Fig. $11 B$ and $11 D$, respectively. B-Close-up of Fig. 11A, showing a large phreatic pocket on right, and smaller ones to the left. C - Te Mata Peak, with dashed line to show the majority of the observed phreatic pockets follow a line that would have been at sea level prior to uplift and tilting. Letters and arrows as in Fig. 11A. D-Small flank margin cave next to person on left, breached phreatic pocket to the right. leothems that formed inside the chambers when they were still sealed (Fig. 14A and 14B). Their position and shape is consistent with a flank margin origin. Just east of the natural bridge at the small harbour east of Pohara, a large talus block rests on the coastal side of the road. Two readily accessible cave entrances are in this block, just centimetres from the roadbed (Fig. 14C). The block contains within it $30 \mathrm{~m}$ of cave passage formed along joints and bedding planes, consistent with the cave passages forming prior to the block tumbling fro the cliff face across the road (Fig. 14D). Phreatic dissolutional surfaces are abundant in the cave, consistent with mixing-zone dissolution and speleogenesis; however, its relationship with the original host environment of the talus block is unknown, and a flank margin designation cannot not made.

Paturau River - Paturau River is located on the northeast coast of South Island, 30 $\mathrm{km}$ southwest of the Golden Bay community of Pakawau (Fig. 3). Telogenetic Takaka Limestone is extensive in this area, and forms a coastal outcrop trending southwest from the community of Paturau River (Fig. 15). The outcrop consists of a low bench 2 to $3 \mathrm{~m}$ high that becomes up to $8 \mathrm{~m}$ high to the southwest (Fig. 15B). A number of small streams and rivulets drain to the coast in the low bench, cutting canyons through the outcrop that are enlarged into oval tubular cross sections in the intertidal zone (Fig. 15A). Farther southwest, the limestone bench broadens, and a small flank margin cave, modified 

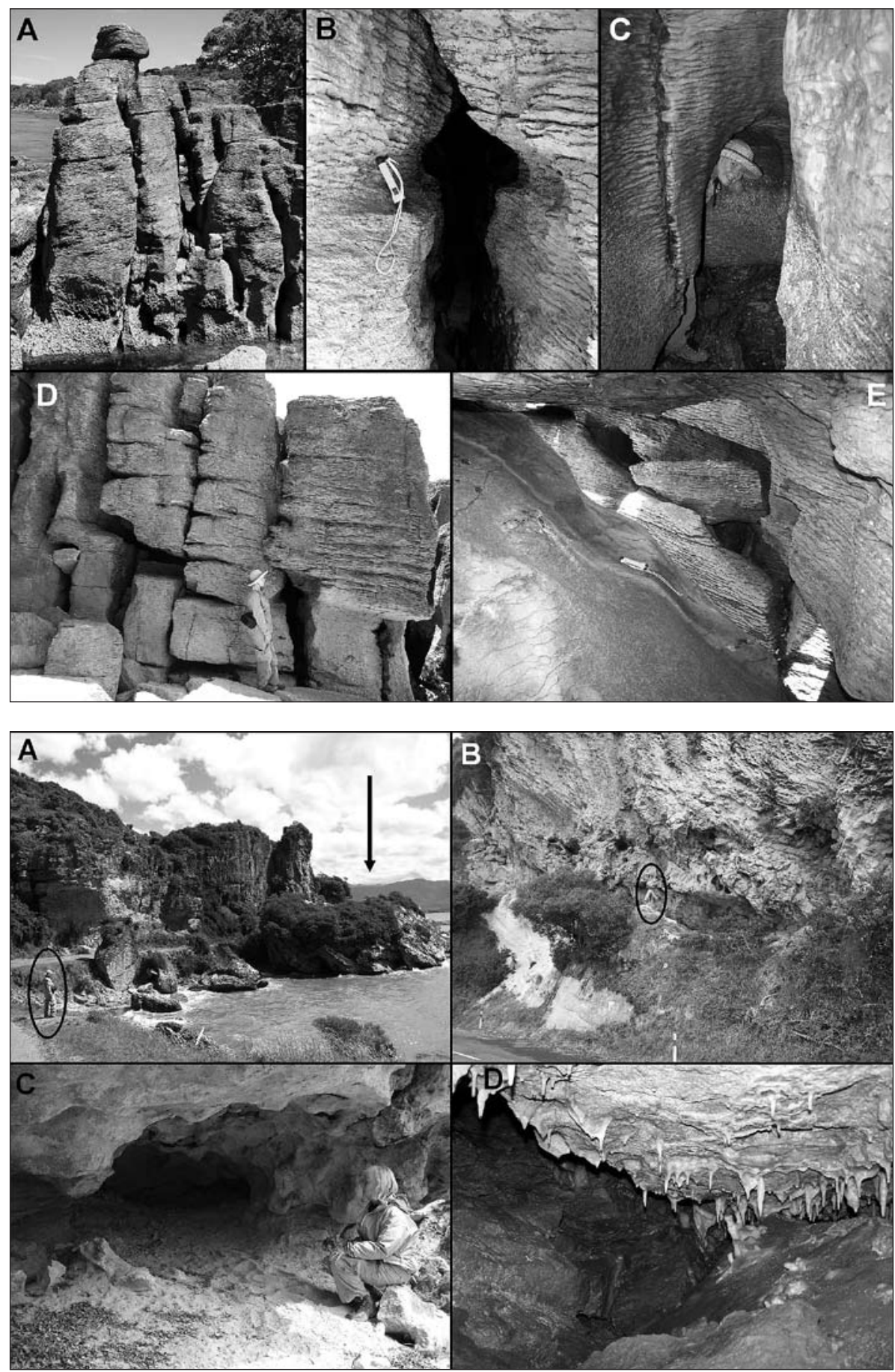

Fig. 13: Pohara-Tarakohe (Oligocene Takaka Limestone). A -Limestone cliffs at Pohara, showing large mega-talus obscuring the actual face of the coastal outcrop. The talus block containing the cave shown in Fig. 14C and Fig. 14D is in the large tree-covered block on right below the arrow seen in Fig. 13A. Person (circled) on left for scale. B - Series of phreatic pockets and flank margin caves following a level horizon that cuts across structure just south of the Abel Tasman Monument. Person (circled) in center of photograph for scale. C - One of the small flank margin caves seen in Fig. 13B. Note the wall pockets and eroded bedrock column (left side of photo), typical of phreatic dissolution. D - Breakdown and flowstone-choked cave just north of Fig. 13B. Soda straws in upper right are $5 \mathrm{~cm}$ long for scale. Note that some of the stalagmites on the block on the right background of the image are not vertical, indicating slumping of the block after stalagmite deposition.
Fig. 12: Waipu Cove district (Oligocene Whangarei Limestone). A - 10 m-tall towers of Whangaeri Limestone at Waipu Cove, isolated by epikarst and marine processes. B - Dissolutional enlargement along a fissure passage; flashlight $15 \mathrm{~cm}$ long. C - Elongated and undulating tube, which dead ends within the limestone outcrop. D - Joints and passages enlarged by dissolution cut across tilted bedding. E - Phreatic passages within the limestone mass are being destroyed as the outcrop retreats in response to wave attack; flashlight $15 \mathrm{~cm}$ long.

by wave erosion, is present (Fig. 16). The cave consists of a chamber $9 \mathrm{~m}$ long by $5 \mathrm{~m}$ wide, breached on two sides, with a large ceiling collapse (Fig. 16A). The presence of bell holes in the ceiling, and other phreatic dissolution features in the cave walls, indicate a dissolutional origin for the void (Fig. 16B). Given the setting and a lack of a conduit continuing inland, the cave is most likely a flank margin cave. Inland on the bench a few meters, are several other smaller phreatic voids that contain delicate bedrock pillars and spans, indicating dissolutional origin (Fig. 16C and 16D). These voids are isolated and not integrated, which agrees with a flank margin mode of origin.

Farther to the southwest, the limestone exposure thickens into a sea cliff at the back of the beach. The cliff has a step in it, and at the back of this step are numerous small notches along a single horizontal datum (Fig. 15B, 15C, 15D). These notches could be intertidal bioero- 

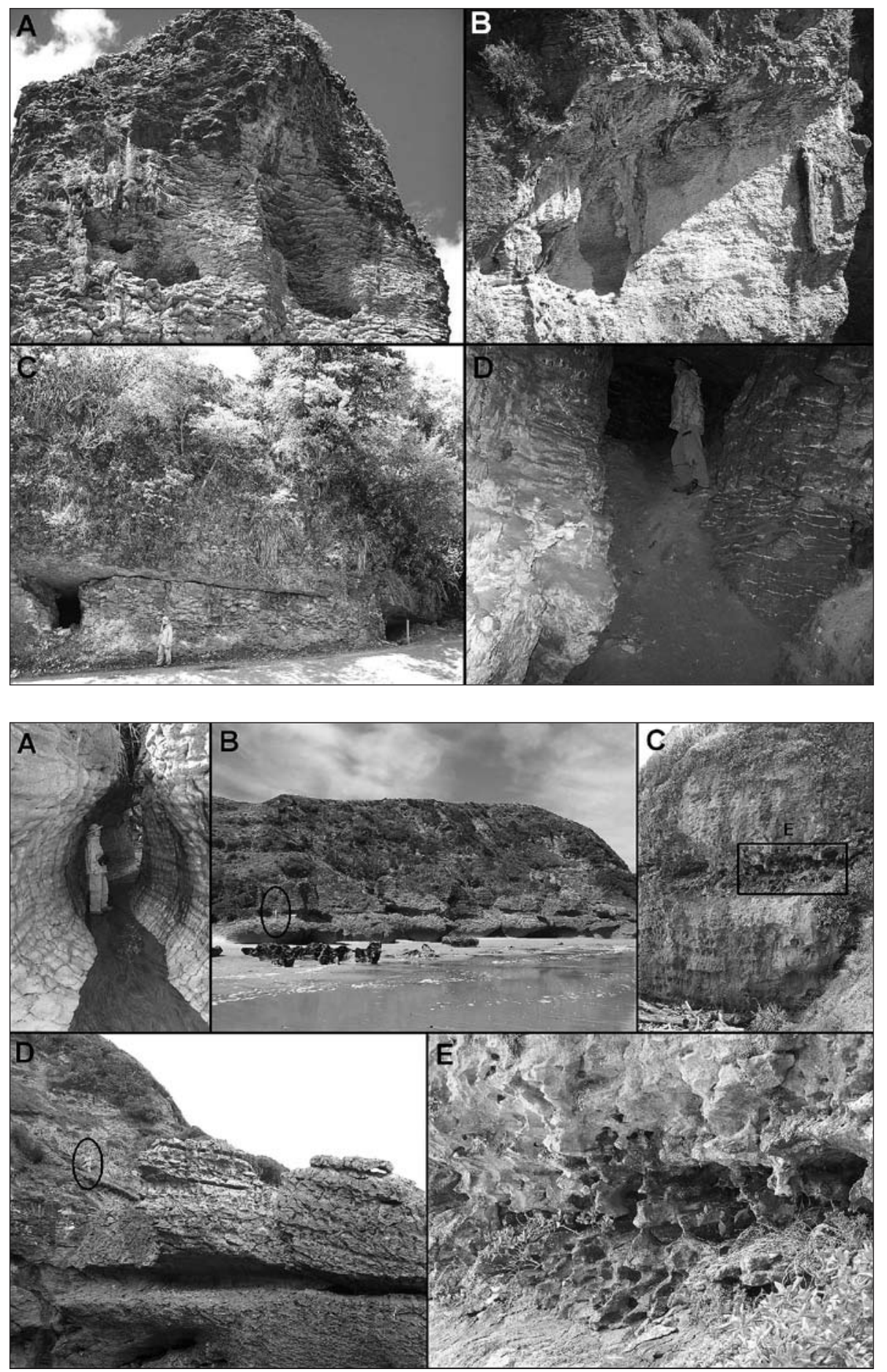

Fig. 15: Paturau River (Oligocene Takaka Limestone). A - Oval passage in the intertidal zone, which carries turbulent stream water from the overlying clastic units through the limestone to the sea. B - Coastal Takaka Limestone outcrop at Paturau River. Person is circled on left for scale. Regular pockets and notches look like a degraded marine-erosion notch, but the presence of dissolutional features indicates a flank margin cave origin for many of these pockets. C - Cliff, $10 \mathrm{~m}$ high, showing large pockets. Boxed section labeled E shown expanded as Fig. 15E. D - Large, undulating notch in cliff shown in Fig. 15B. Person circled for scale. E-Close up of the pocket shown in Fig. 15C. The delicate rock fretwork shown here is a product of phreatic dissolution in a cave chamber, and not from wave erosion in an open environment.
Fig. 14: Pohara-Tarakohe (Oligocene Takaka Limestone). A - Cliff with a breached phreatic pocket on the right (approximately $5 \mathrm{~m}$ in vertical height), and exposed cave flowstone on the left. B -Breached phreatic pocket with cave stalactites hanging from the remnant ceiling; the large flowstone column to the far right is approximately $3 \mathrm{~m}$ long. $\mathrm{C}-\mathrm{Two}$ entrances to the dissolution cave within the large talus block noted in Fig. 13A. D - Passage inside the talus block that connects the two entrances, showing dissolutional morphology.

sion notches from an earlier sea level, except that some contain delicate phreatic dissolutional features and small phreatic tubes (Fig. 15E), suggesting an origin as flank margin caves within the bedrock mass, and subsequently breached by cliff retreat.

Punakaiki - Telogenetic Oligocene Waitakere Limestone trends in a band parallel to the west coast of South Island from Charleston, $20 \mathrm{~km}$ south of Cape Foulwind, south to Punakaiki (Fig. 3). The outcrop is mostly inland, but reaches the coast south of Fox Creek at an area called Limestone Creek, and again at the classic Pancake Rocks outcrop at Punakaiki. The Pancake Rocks outcrops are in a national park and the sea cliffs are not routinely accessible. Observation from the tourist trails indicates that the cliffs have numerous openings into shallow caves (Fig. 17), but the origin of these caves could not be determined. At the north end of the park, on the east side of the road, is the entrance to Punakaiki Cavern, a self-guided tour. The 


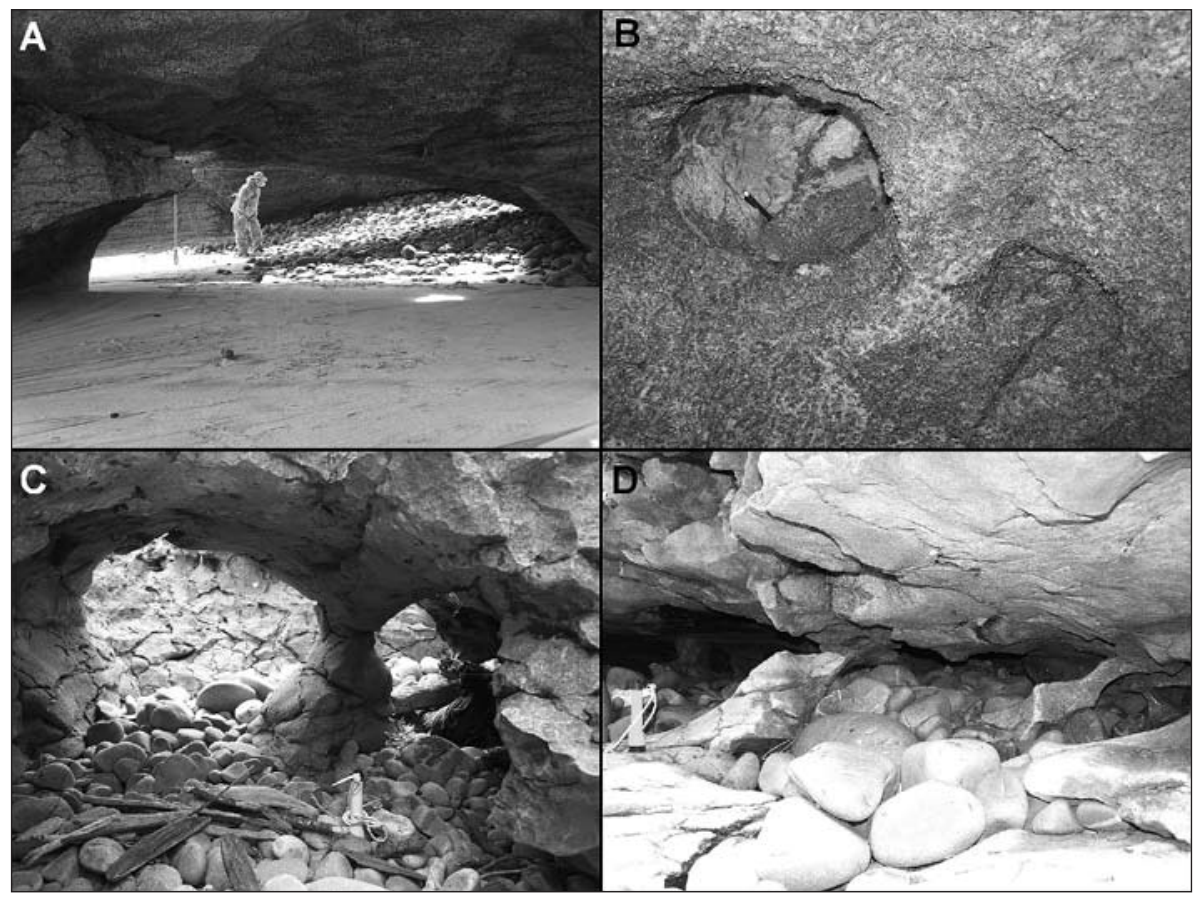

Fig. 16: Paturau River (Oligocene Takaka Limestone). A - A breached flank margin cave at Paturau River. B - Bell holes in the ceiling of the cave chamber shown in Fig. 16A. Note pencil $15 \mathrm{~cm}$ long for scale stuck in the left bell hole. $C$-Small phreatic cave chamber breached by wave erosion, $10 \mathrm{~m}$ inland of the cave shown in Fig. 16A. The cave is in the early stages of destruction, as the thin bedrock pillar is still intact. Flashlight $15 \mathrm{~cm}$ long for scale. D - Another small phreatic cave, inland of the cave shown in Fig. 16A. Bedrock pillar on the left was partially dissolved from its ceiling connection prior to the cave being breached. The angled bedrock pillar to the right is fragile but still intact. Flashlight $15 \mathrm{~cm}$ long for scale.

cave is a large chamber tens of meters across and deep, much modified by collapse, with fissure passages leading inland and terminating. It is difficult to determine if the cave is a fragment of a conduit system, or the result of mixing dissolution.

At Limestone Creek, a few kilometres north of Pancake Rocks (Fig. 3), coastal outcrops are accessible from the beach. A number of small caves exist at the south end of the beach next to Limestone Creek. Proceeding north, two very important outcrops are reached. Limestone Creek Through Cave is a phreatic passage developed along joints that passes for $30 \mathrm{~m}$ through a small limestone headland (Fig. 18). The passage averages several metres high and wide, but becomes smaller at each end. The cave has no indications of high-velocity, turbulent conduit flow, such as scalloping of passage walls. The main cave passage splits, and a large side passage trends into the seaward side of the headland and ends in a blank bedrock wall, a hallmark of flank margin cave dissolution (Fig. 19).

Farther north along the beach, is an area named Tube City. In this outcrop, numerous phreatic tubes exist on a horizontal datum that cuts across the bedding and jointing (Fig. 20). The dip of the bedding in this outcrop is $20^{\circ}$ to the SSE (Fig. 21). The jointing is closely spaced, dipping at 650 to the NNE. The caves in the outcrop face, as shown by the wave-cut limestone bench in front of them (Fig. 20B), were once enclosed. The phreatic tubes trend inland up to $5 \mathrm{~m}$, before closing down to a single joint (Fig. 20C). The tubes contain layers of flowstone on their walls, indicating they were once closed chambers and have been breached by modern wave activity (Fig. 20C). A total of 7 phreatic tubes are found in an outcrop span of $44 \mathrm{~m}$, all tube floors being between 3 and $5 \mathrm{~m}$ above sea level. Dead-end phreatic tubes without turbulent flow markings, such as scallops, at a constant elevation cutting across structure, are some of the indicators of a flank margin origin (Fig. 20D).

Kakanui - On the east coast of South Island, approximately $12 \mathrm{~km}$ south of Oamaru, at Kakanui Point at the north end of All Day Bay, the Oligocene Ototara Limestone, and the overlying Otekaike Limestone, crop out in a coastal setting (Fig. 3). Both limestone units are topped by an unconformity displayed as a well-developed paleokarst surface. The paleokarst surface of the Ototara extends seaward and eastward as a low limestone bench from the south side of Kakanui Point (Fig. 22A and 22B). In the bluff behind that beach are a series of small, lenticular voids up to $2 \mathrm{~m}$ wide and $0.5 \mathrm{~m}$ high, that cut across the primary limestone structure in the outcrop (Fig. 22C and 22D). These voids have bedrock pendants and residual columns typical of phreatic dissolution, but lack any evidence of conduit flow, and exist as isolated chambers. They meet the field criteria for flank margin caves.

Kaikoura - Telogenetic Paleocene Amuri Limestone and overlying Oligocene Grey Marl crop out in a coastal setting on the Kaikoura Peninsula in northeastern South Island (Fig. 3). Compared to the medium to very coarse-grained bioclastic carbonates characterizing all the other New Zealand limestones studied, the Amuri Limestone is an indurated very fine-grained 


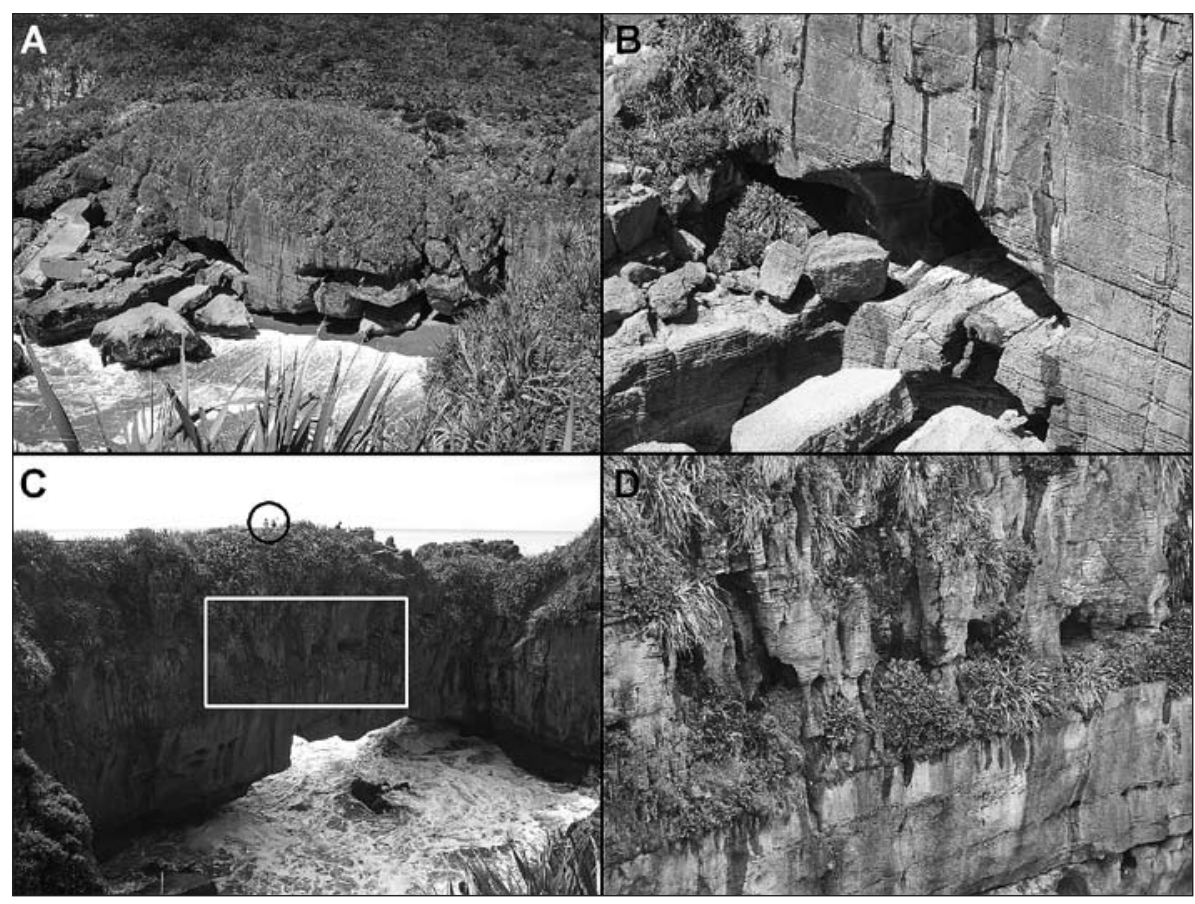

Fig. 17: Punakaiki (Oligocene Waitakere Limestone). A Coastal outcrop at the north end of the self-guided tour at Punakaiki, showing cave entrances. $B$ - Close-up of the middle entrance shown in Fig. 17A. C - Natural bridge at Punakaiki. A horizon of dissolution pockets and voids is visible halfway up the bridge, in box. People on horizon (circled) for scale. D - Close-up of the pockets and voids noted in the box of Fig. 17C.

limestone, or micrite. The Kaikoura area is geologically complex, with folding and faulting leading to a complex outcrop pattern. The tectonics has created a very fractured and jointed limestone (Fig. 23A and 23B).

\section{LIMESTONE CREEK THROUGH CAVE}

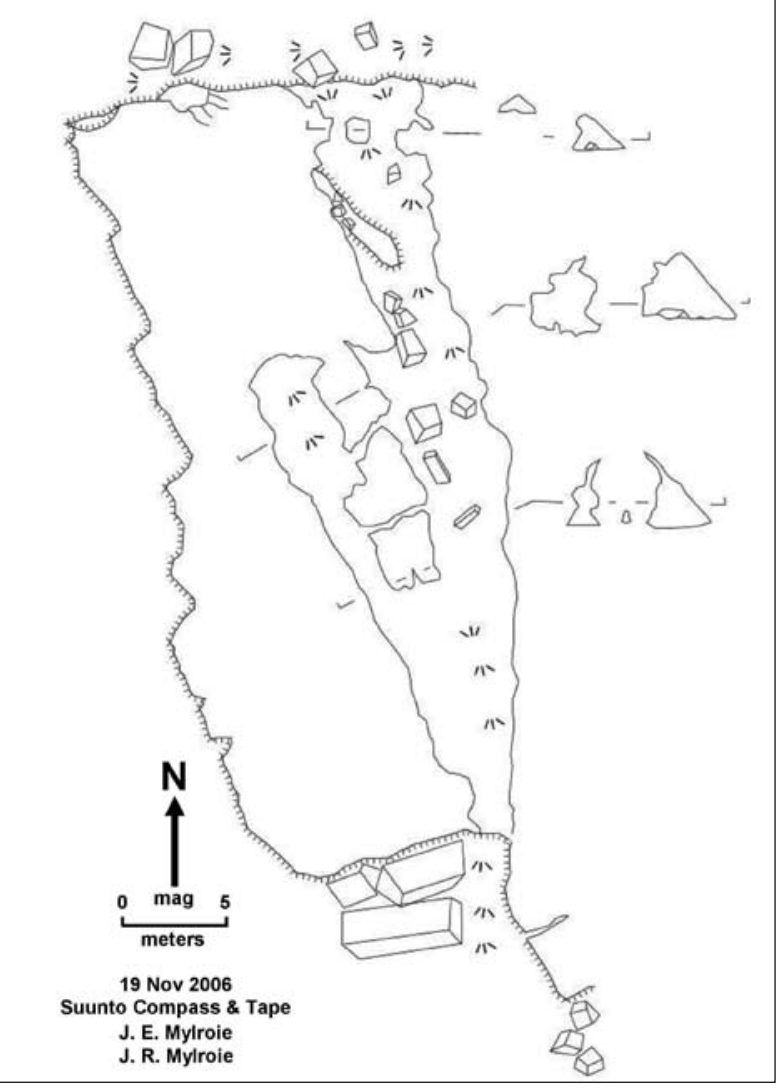

Fig. 18: Map of Limestone Creek Through Cave.
The initial feature is a small cave on the north side of the peninsula, on the outskirts of the main town, just west of the road leading to the wharf. In a low vertical face trending N-S is an entrance to a small cave $6 \mathrm{~m}$ deep and $4 \mathrm{~m}$ wide, 1 to $1.5 \mathrm{~m}$ high (Fig. 23C and 23D). Several small dissolution pockets are nearby on the cliff face. The interior of the cave is somewhat shattered, but phreatic dissolution pockets are still discernible in the roof and walls of the cave (Fig. 23D). It appears to be an isolated chamber and, given its setting, therefore a small flank margin cave.

Moving east along the north coast of the peninsula, the Amuri Limestone outcrop disappears at Avoca Point, to be replaced by the Grey Marl. Going around Point Kean, and continuing southwest, the limestone outcrop again appears, and a small cave, $2 \mathrm{~m}$ high, $0.5 \mathrm{~m}$ wide, and $3 \mathrm{~m}$ deep opens at the base of a steep hill. The cave walls are shattered and irregular, and the origin of the cave is difficult to determine. It could be a sea cave or a dissolution cave.

No caves were located for about the next kilometre going southwest, but around East Head, on its southwest side, behind trees at the base of the cliff, is Kaikoura Point Sea Cave (it is marked as a sea cave on a tourist map), a large dissolution cave (Fig. 24). The entrance is $5 \mathrm{~m}$ wide and $5 \mathrm{~m}$ high, with a triangular cross section (Fig. 25A and 25B). The passage leads northeast, as an oval tube 3 to $5 \mathrm{~m}$ wide, and $3 \mathrm{~m}$ high, with an additional dissolutional slot in the ceiling a metre wide (Fig. 25B). The passage continues for $30 \mathrm{~m}$ to a terminal chamber $14 \mathrm{~m}$ 


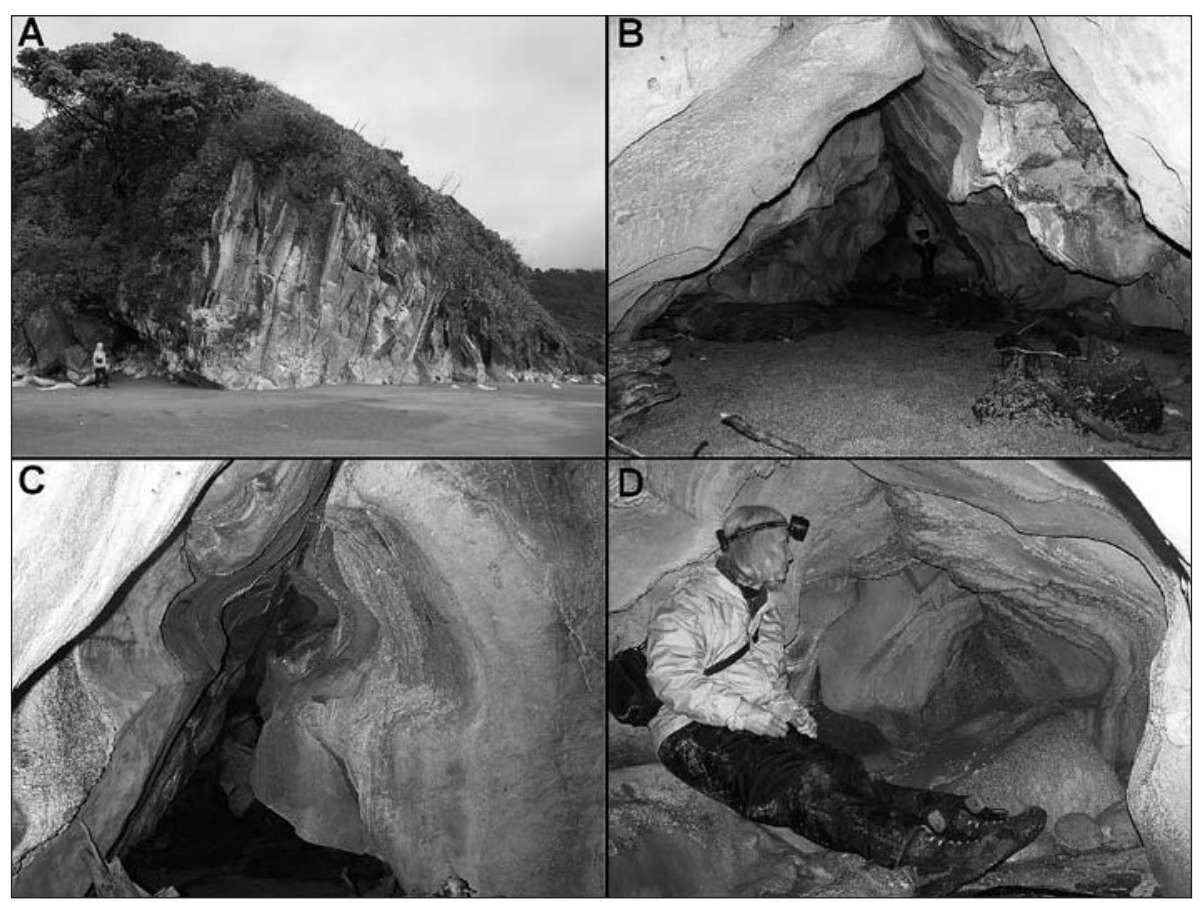

Fig. 19: Punakaiki (Oligocene Waitakere Limestone). A -Point containing Limestone Creek Through Cave. Note that the bedding dips from left (north) to right (south). Person on left for scale. B - The main passage in Limestone Creek Through Cave, formed by dissolution at the intersection of a bedding plane and joint. Person sitting at end of the passage for scale. C-Passage developed along a joint, with a dissolutional widening that is horizontal despite steep dip of the bedding. This passage leads to the chamber seen in Fig. 19D. Person sitting low in the distance for scale. D-Terminal chamber, with passage pinching down along the guiding joint seen in Fig. 19C.

wide and $4 \mathrm{~m}$ high (Fig. 25C). The cave ends in bedrock walls. The cave walls contain numerous dissolution pock- ets, evident despite the shattered and irregular nature of the cave walls (Fig. 25D). A smaller cave exists $5 \mathrm{~m}$ to the right (east) of the main cave, and is $4 \mathrm{~m}$ long (Fig. 24 and Fig. 25A). These caves appear to match the conditions for flank margin cave development.

West and southwest from East Head, and approaching Atia Point, the limestone outcrop again ends, to be replaced by the Gray Marl. A few tens of meters east of this contact, a small limestone point contains two relatively large caves, collectively named Kaikoura Penguin Cave (Fig. 26). The caves run northeast to southwest, parallel to one another, one inland of the other, both with entrances on each side of the point. The more inland cave is entered by ascending and descending a large collapse pile, which leads to a voluminous entrance chamber (Fig. 27A). Trending northwest from the entrance chamber is a passage $16 \mathrm{~m}$

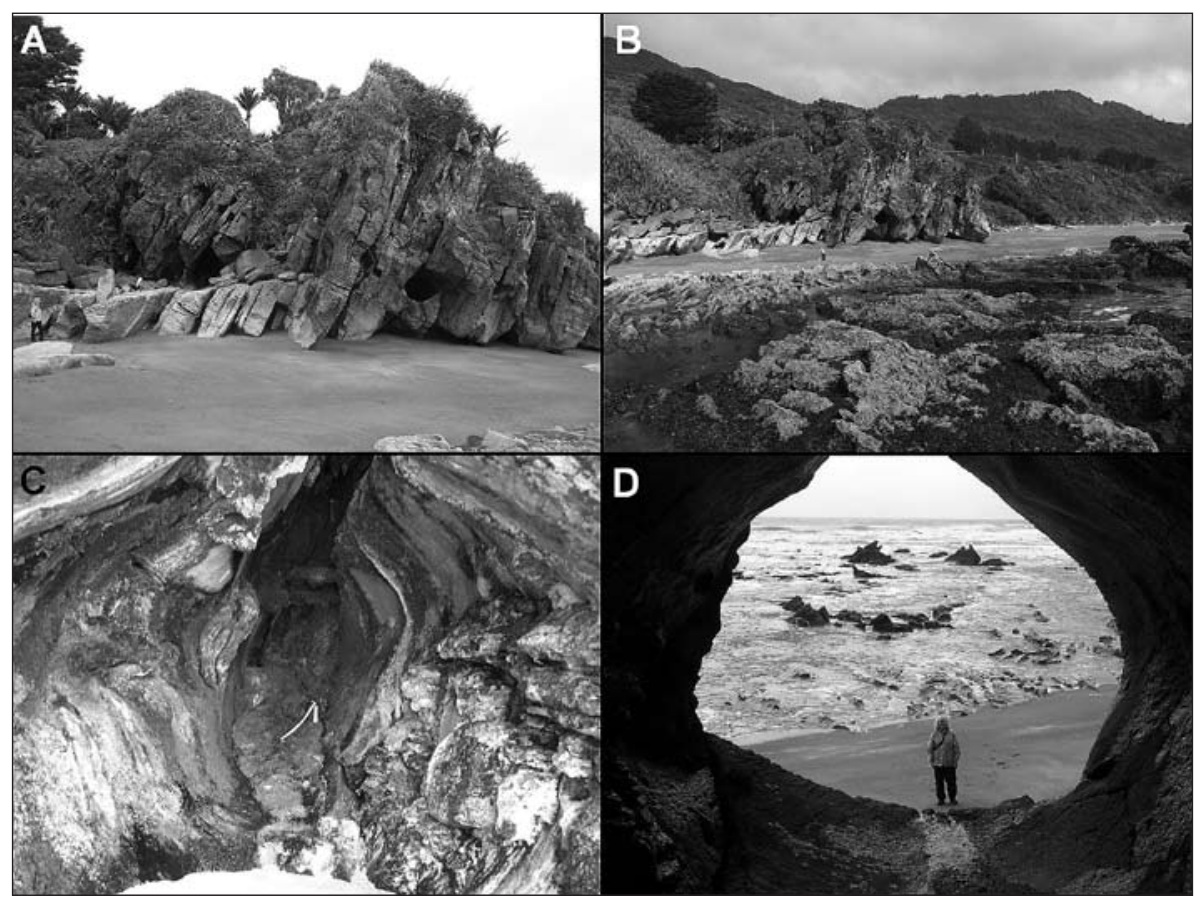

Fig. 20: Punakaiki (Oligocene Waitakere Limestone). A - Tube City outcrop on the Limestone Creek coast. Seven individual tubes, all within 1 or $2 m$ of the same elevation, are in the outcrop. The bedding dips from left (north) to right (south), and the jointing is very closely spaced. Person at left for scale. B - Tube City outcrop from a distance, showing the wavecut platform in front of the caves, indicating significant shoreline retreat in this location. C - View inward in the large phreatic tube seen on the right in Fig. 20A. Note how the bedrock walls pinch down to the guiding joint, and the horizontal flowstone horizons on the right wall, and in the back. Flashlight is $15 \mathrm{~cm}$ long for scale. D - Looking out the same tube as in Fig. 19C, across the wave-cut platform. 


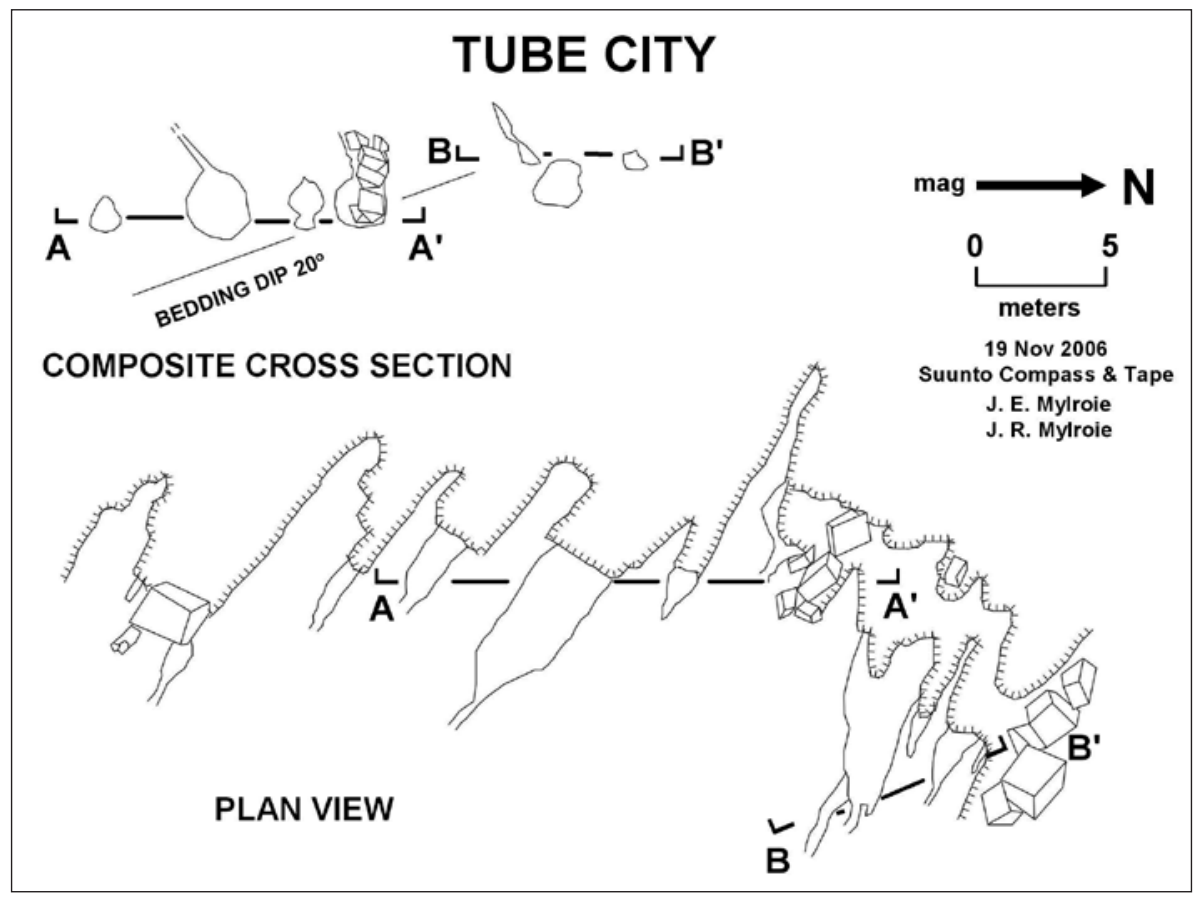

Fig. 21: Map of the Tube City outcrop, plan view and composite section. Compare with Fig. 6 B.
27B). Southwest from the entrance chamber, a high, narrow passage heads $28 \mathrm{~m}$ directly through the limestone outcrop to a small entrance on the far side (Fig. 27C). The passage starts out $10 \mathrm{~m}$ high and $3 \mathrm{~m}$ wide, sloping upward to the southwest so that at the far entrance, the cave is only $1 \mathrm{~m}$ wide and 0.5 $\mathrm{m}$ high. The cave floor is mud and sediment, and the nature and position of the bedrock floor cannot be determined. This passage has a number of dissolution pockets in the side walls and ceiling, consistent with a phreatic origin.

Seaward of the first cave is a second cave that also runs from the northeast to the southwest, through the limestone point (Fig. 28A). long, $5 \mathrm{~m}$ wide and $3 \mathrm{~m}$ high. This passage has well developed dissolution pockets and small chambers developed along its length, and it terminates in bedrock walls (Fig.

There are two additional entrances that open to the south on the face of the limestone point (Fig. 28B). The western of these two entrances is at an elevation low enough

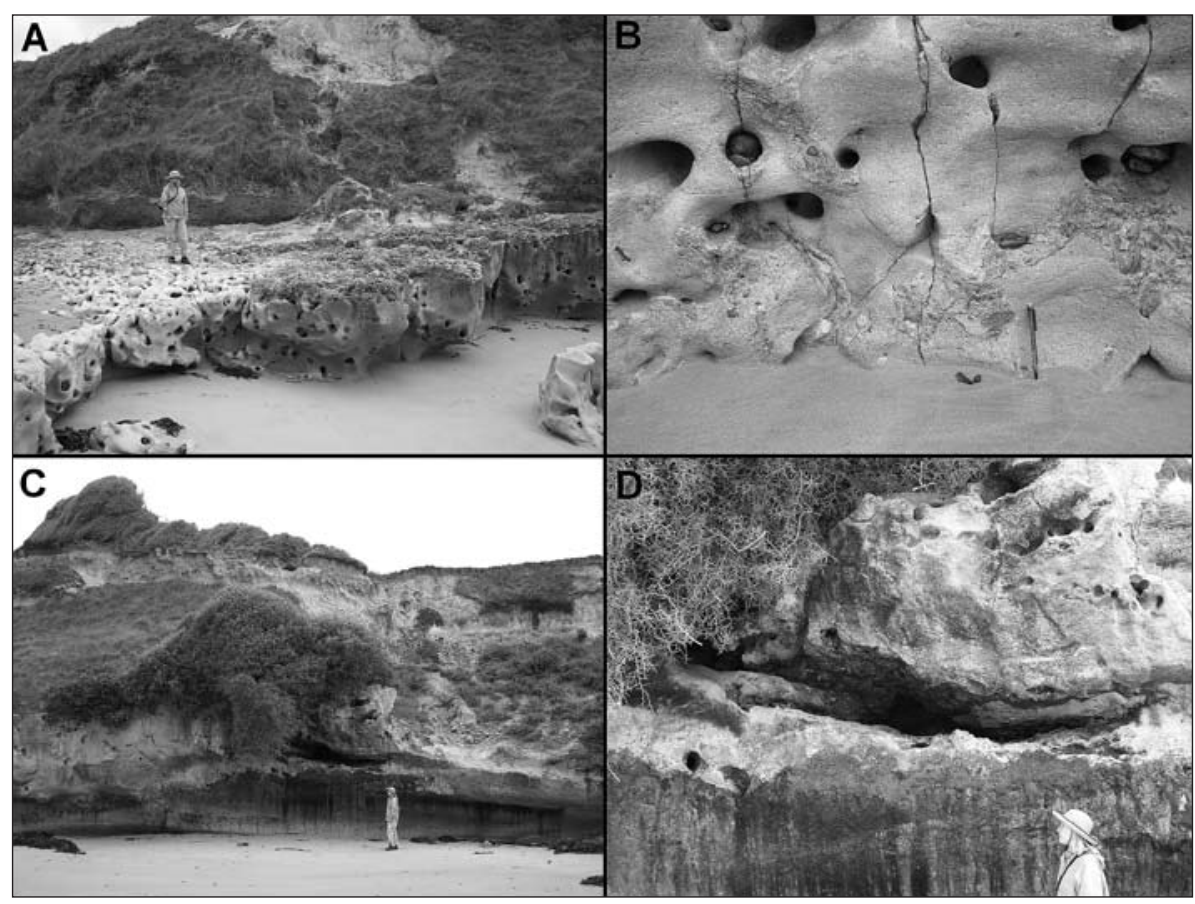

Fig. 22: Kakanui (Oligocene Ototara Limestone). A - Outcrop of Ototara Limestone with paleokarst surface exposed. B - Close-up of the outcrop in Fig. 22A, showing paleokarst infillings. Pencil $15 \mathrm{~cm}$ long for scale. $C$ - Flank margin cave in the cliff face. $D$-Close-up of the cave entrance seen in Fig. 22C. to have back-beach cobble rubble on the floor (Fig 28B). The southwestern entrance on the far side of the limestone point has some collapse debris blockage (Fig. 28C). As with the inland cave, the northeastern entrance is dominated by a large pile of cliff collapse (Fig. 28D). The two entrances to the south are unobstructed. The main passage through the limestone point is $40 \mathrm{~m}$ long, and up to $5 \mathrm{~m}$ high and wide. Short side passages trend northwest towards the first cave but end in bedrock walls. The passages leading south to the southern entrances are $10 \mathrm{~m}$ long. The passage to the northeast is 5 $\mathrm{m}$ high and $3 \mathrm{~m}$ wide, while the passage to the southwest is $2 \mathrm{~m}$ high and wide.

The two caves both show phreatic dissolutional 


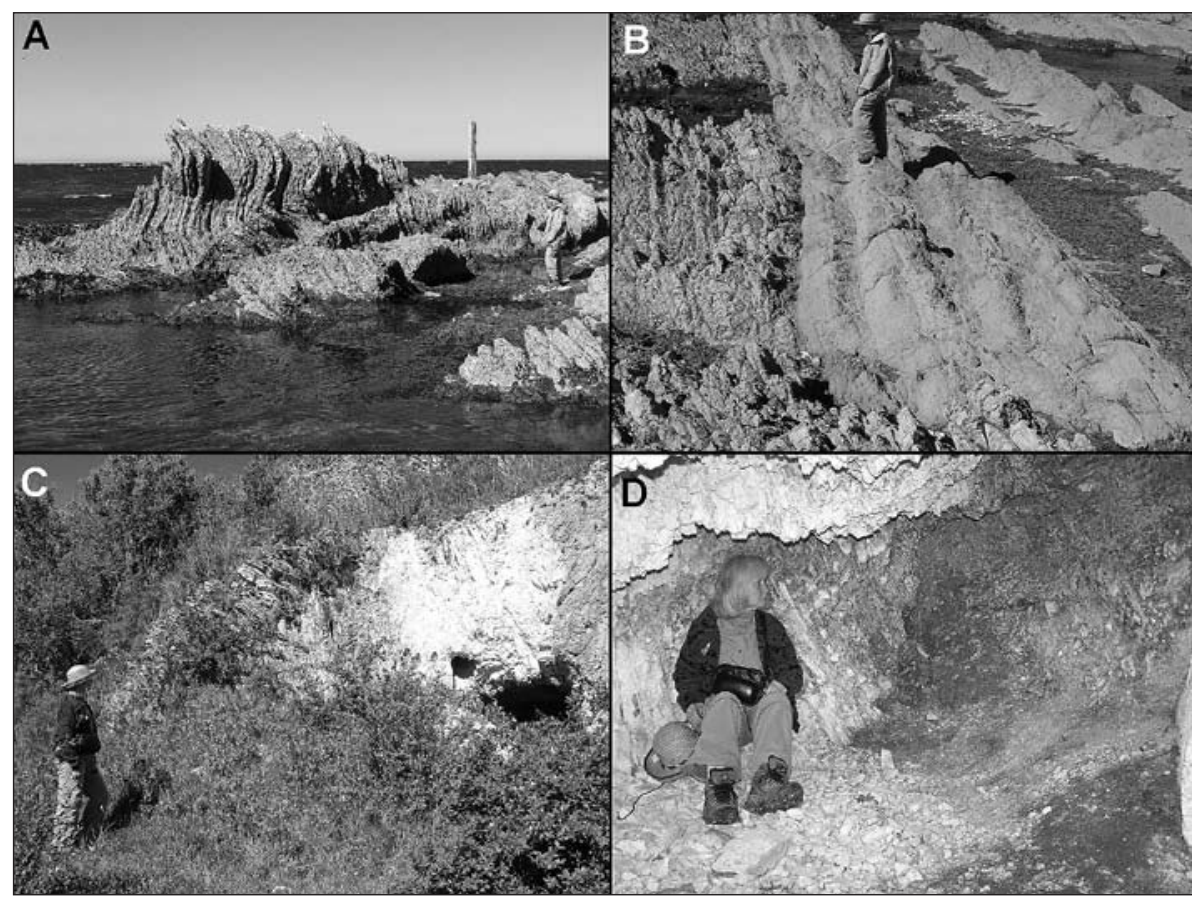

Fig. 23: Kaikoura (Paleocene Amuri Limestone). A - Folded beds of the Amuri Limestone distorted to a vertical position, north side of Kaikoura Point. B - Contact of the Amuri Limestone, left, with the Grey Marl, right. Note in foreground that faulting has displaced the contact. $C$ - Entrance to a small flank margin cave, north side of Kaikoura Point. The small phreatic pocket above and to the left does not connect with the cave. D - Single chamber that forms the cave. Note the shattered nature of the limestone walls and ceiling, and the dissolution pocket at the back of the chamber, to the right of the person. surfaces and passage complexity, but are not currently connected. They pass through the limestone point containing them, and appear to have been opened by cliff retreat, demonstrated by the broad wave-cut bench in front of the point (Fig. 28A). The walls contain no turbulent flow markings. The caves seem to fit the criteria for flank margin development.

A few kilometers south of Kaikoura Peninsula, just west of Highway 1, is Maori Leap Cave, a show or commercial cave. The cave was opened from above by limestone quarrying, but rubble infill was removed to open the cave horizontally on the Amuri Limestone cliff face. The cave is a single passage, about $100 \mathrm{~m}$ long, up to $8 \mathrm{~m}$ high and $6 \mathrm{~m}$ wide, perpendicular to the cliff face. There is much collapse material in the cave, and all original dis-

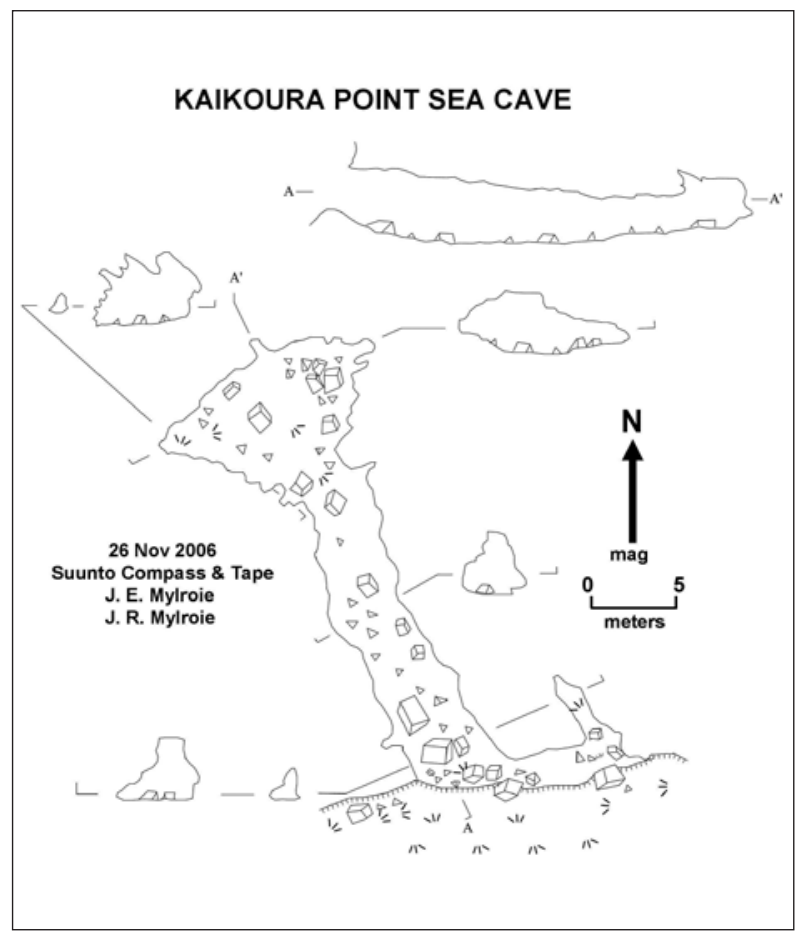

Fig. 24: Map of Kaikoura Point Sea Cave.

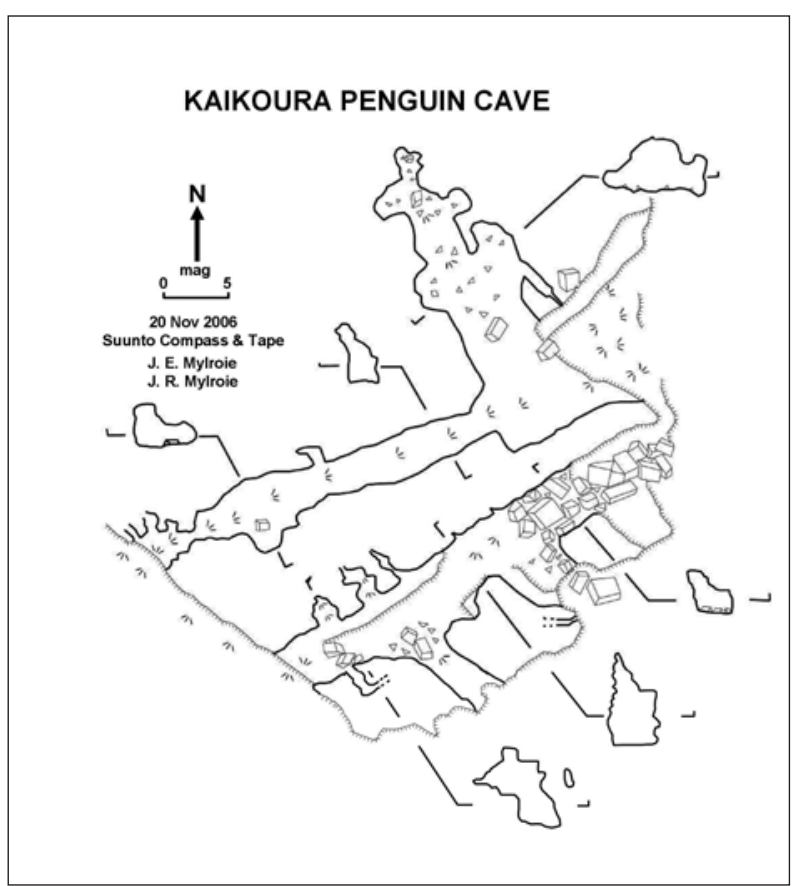

Fig. 26: Map of Kaikoura Penguin Cave, which is actually two separate caves. 


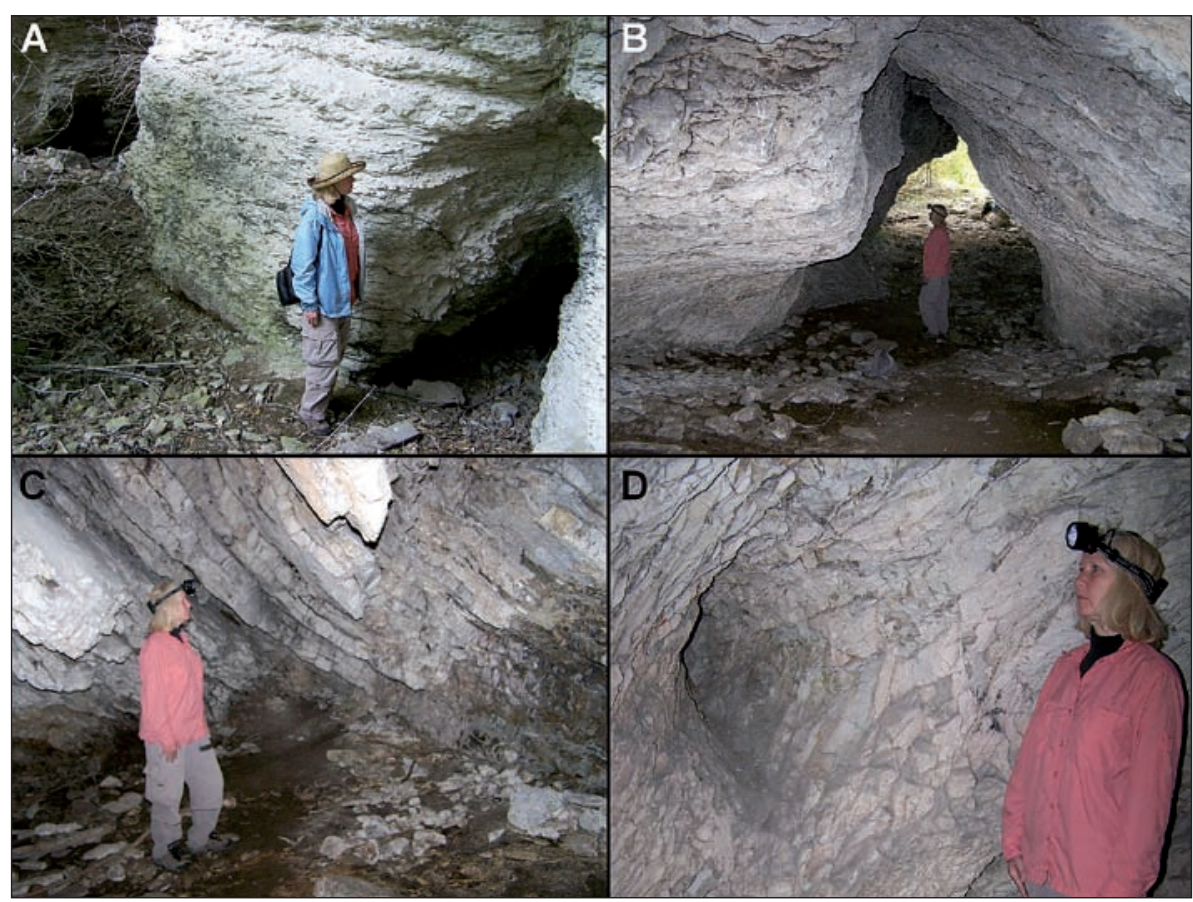

Fig. 25: Kaikoura (Paleocene Amuri Limestone) - Kaikoura Point Sea Cave. A - Entrance area of Sea Cave; main entrance is in the background, secondary cave entrance is in the foreground. $B$ - Main passage in Sea Cave. Note ceiling slot. Beds dip towards the camera. C - Terminal room in Sea Cave, looking west. Note steeply-dipping (up to $\left.55^{\circ}\right)$ beds. D - Phreatic pocket in wall of the main passage of Sea Cave. The pocket is directly behind the person in Fig. $25 B$.

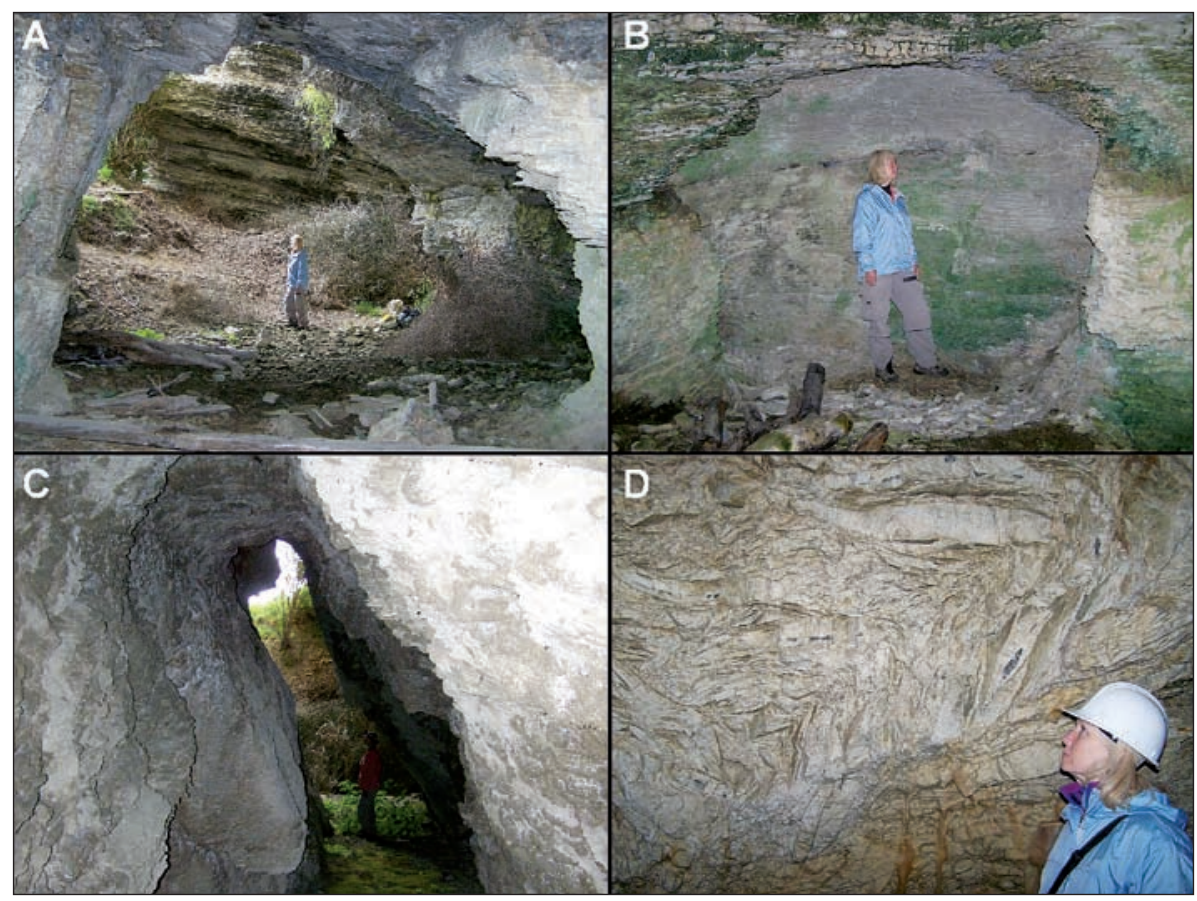

solutional surfaces (if originally present) are gone. The cave is presented on the tour as a fossil sea cave, but there is no evidence for either that origin or a dissolutional speleogenesis. The cave is very long relative to its width, and propagation of wave energy to such a penetration seems unlikely. The walls of the cave display many folds and small faults, as well as chert, and the limestone is highly fractured (Fig. 27D). The collapse material is made up mostly of blocks less than 1 meter in maximum dimension, and commonly only $20 \mathrm{~cm}$ or so in maximum dimension.

Fig. 27: Kaikoura (Paleocene Amuri Limestone) - Kaikoura Penguin and Maori Leap Caves. A - Looking south into the entrance chamber of the inland of the two Kaikoura Penguin Caves. $B$ - Side pocket in left wall of the passage shown in Fig. 27A, displaying smooth, phreatic origin. $C$-View northeast in the passage that cuts through the point in the inland cave. Note the smooth, curved ceiling of this passage, indicating a phreatic origin. D - Folded and distorted wall rock in Maori Leap Cave. 


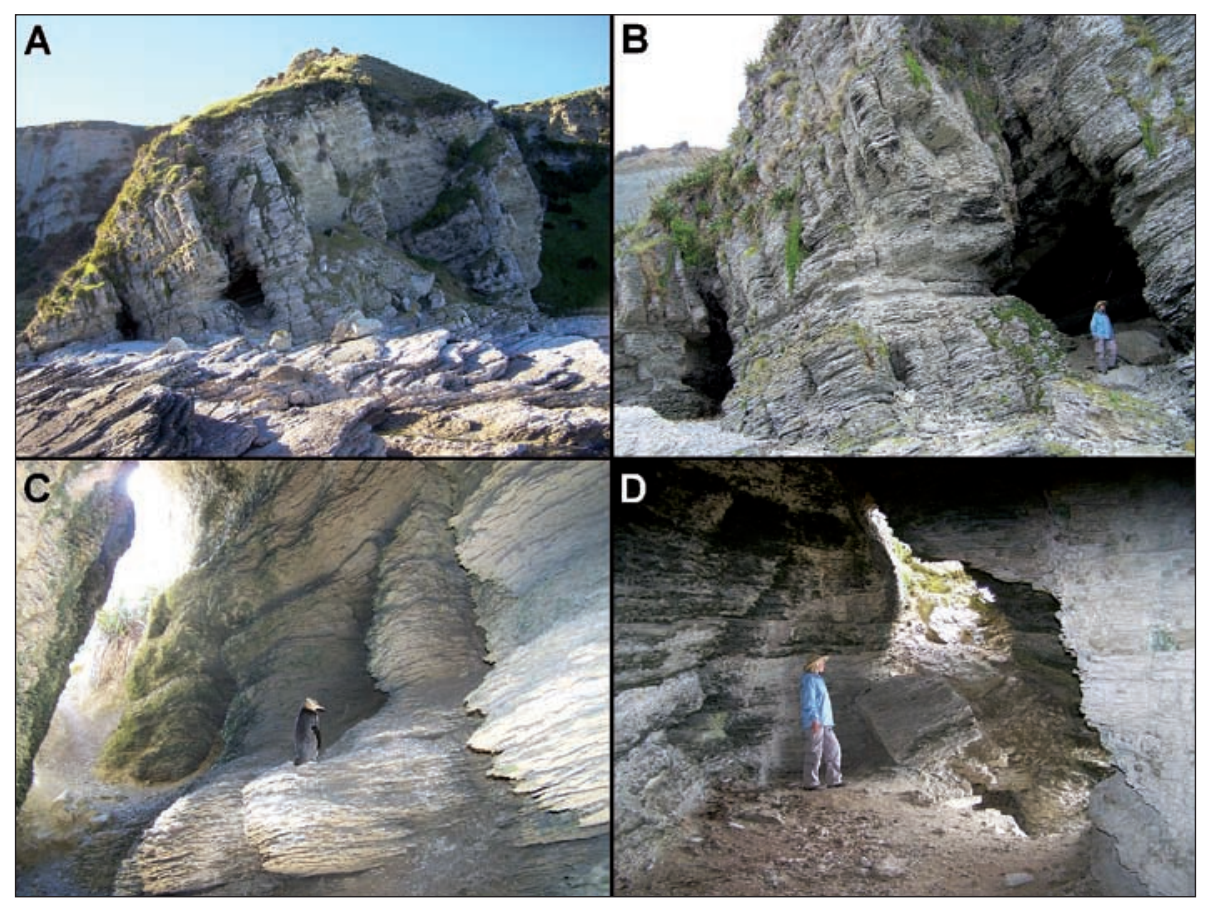

Fig. 28: Kaikoura (Paleocene Amuri Limestone) - Kaikoura Penguin Caves. A - Limestone point containing the two Kaikoura Penguin Caves. Note that the caves have been breached by erosion and planation of the bedrock outcrop in front of the point. B - The two southern entrances into the seaward of the two Kaikoura Penguin Caves. Note the cobbles in the floor area of the western (left) entrance. C - Main passage of the seaward cave. Penguin for scale is $1 \mathrm{~m}$ high. To the left is the southwestern entrance, passages ahead of the penguin end in bedrock walls before reaching the inland cave. D - Looking northeast to the northeastern entrance of the seaward cave. The person is illuminated by light from the easterly (right) of the two entrances seen in Fig. 28B. The wall behind the person shows dissolutional smooth, curvilinear morphology.

\section{DISCUSSION}

Distinguishing cave origins - Caves located in limestones in coastal settings can be of a variety of origins. They can be pseudokarst caves, formed by processes other than dissolution. Examples would be talus caves formed by cliff collapse, tafoni by surficial weathering, or sea caves formed by wave erosion. The caves can also be true karst caves of dissolutional origin. Talus caves are self evident, although as shown by the example at Pohara, talus blocks may contain dissolutional caves present in the rock prior to cliff collapse (Fig. 14C and 14D). Tafoni caves can be differentiated from dissolutional caves by morphometrics (Owen, 2007). If the original bedrock surfaces from the time of cave genesis are preserved, differentiating pseudokarst sea caves from dissolutional karst caves is relatively straight forward. Dissolution of limestones to create a cave leaves behind a variety of bedrock forms and shapes that are different from those produced by mechanical erosion by wind, or by waves and wave-entrained debris. When a dissolution cave opens onto a coastal environment, wave action may enter the cave and obscure the original dissolutional surfaces, creating confusion as to origin. This alteration is of particular importance for flank margin caves, as small ones, once breached, commonly may not extend beyond the influence of wave action, and their entire interior may be modified. Even in this case, use of morphometrics has allowed sea caves to be differentiated from flank margin caves in the Bahamas (Waterstrat, 2007) and in Puerto Rico (Lace, 2008) based on shape parameters such as area to perimeter ratio, and entrance width to maximum interior width ratio. Dense, well crystallized secondary calcite speleothems - stalactites, stalagmites, flowstone, etc., should not form in sea caves, even when subsequently abandoned by sea level, as such speleothems do not develop in an open atmosphere environment. Given that calcareous tufa, which can crudely mimic cave speleothems, can form in abandoned 
sea caves, criteria for differentiating the two should be utilized, as presented in Taboroši et al. (2006).

The situation becomes more complex when attempting to discriminate between mixing zone dissolution and flank margin cave formation within a fresh-water lens, and high-velocity, turbulent conduit flow in a cave stream passage. In a setting such as the Bahamas, where conduitflow stream caves do not exist today, such discrimination is not necessary (Mylroie et al., 1995). In more complex carbonate island settings, such as the Mariana Islands, stream conduit caves form at the contact between carbonates and underlying volcanics, while in adjacent solely carbonate coastal areas, flank margin caves have formed (Jenson et al., 2006). If a conduit cave is still active, it may be possible to enter the cave and see the turbulent flow in situ. Flank margin caves form by dissolution within the bedrock mass; reactants enter, and products leave, by diffuse flow. The caves develop without entrances and therefore are difficult to view in situ. Flank margin caves are observed after sea level change (either eustatic or tectonic) has placed the cave above sea level, and erosion has breached into the cave, making it accessible.

Conduit-flow stream caves, when they discharge their water back to the surface environment, commonly form a distributary pattern analogous to the distributary pattern of deltas. A drop in base level as a result of sealevel change can lead to abandonment of a set of distributary passages. Further erosion may incise and segment such a set of cave passages, to produce a local abundance of small caves. Additional erosion may obscure the genetic relationship of these cave fragments to each other. The observer coming to a coastal environment may see a series of small caves that contain evidence of dissolutional development. The consistent elevation of these caves, and their location at a sea coast may lead to a conclusion of cave development in the fresh-water lens during a past, higher sea level. The caves may be incorrectly interpreted as flank margin caves.

Caves in telogenetic carbonates - In eogenetic carbonate rocks, with high primary porosity, fresh water and seawater mix over a broad front, and diffuse flow of reactants and products occurs over a large area. The end results are broad, globular chambers and mazes that intersect to form caves of some complexity, but are separated from nearby caves as there is no integration or conduit flow in such an environment (Fig. 1). These caves are easily differentiated from conduit caves based on cave morphology, and the absence of high-velocity turbulent flow indicators. In dense, telogenetic carbonate rocks present in New Zealand, where flow permeability is along bedding planes, joints, and fractures, and matrix porosity is minimal, mixing dissolution is concentrated along those flow paths, and not in the matrix. As a result, mixing dis- solution caves such as flank margin caves would be expected to have a passage pattern that reflected bedding, joint, and fault orientations and trends.

To differentiate flank margin caves formed in telogenetic rocks from stream conduit caves formed in telogenetic rocks therefore requires close observation. Two main observational differences should remain true:

1) telogenetic flank margin caves should show no evidence of high-velocity turbulent or conduit flow, in both wall rock dissolutional morphology, and in interior sediments;

2) passage relationships in telogenetic flank margin caves should show no dendritic or organized links with adjacent caves, and should contain passages and chambers that end in blank bedrock walls. Again, morphometrics have successfully been used to distinguish flank margin caves from conduit-flow stream caves (Roth, 2004; Roth et al., 2006).

Flank margin cave size is a result of the geochemistry at the distal margin of the fresh-water lens, the nature of the host carbonate rock, and the duration of time that the fresh-water lens is at a single horizon. Given that sea water and fresh water chemistries tend to fall within standard limits, the main geochemical difference is most likely related to the degree of organic loading of the density boundaries at the top and bottom of the lens. There is no effective way to judge past organic loading, except that when it is excessive and leads to anoxic conditions, it can leave a signature in the cave wall rock (Bottrell et al., 1993). The host carbonate rock influences flank margin cave size based on two parameters: the amount and distribution of rock porosity and permeability, and the amount, chemistry, and purity of the carbonate material. These properties can be determined from outcrop sampling. The duration of time that the geochemical environment of the fresh-water lens remains in the same section of carbonate rock is tied to sea-level stability. The longer the lens is in a stable position, the more geochemical dissolutional work that can be done and the bigger the flank margin cave produced (Mylroie \& Mylroie, 2007). Sea-level histories for coastal areas in tectonically-active environments such as coastal New Zealand can be difficult to determine (Pillans 1986).

The New Zealand situation - Despite the tectonically-active environment of coastal New Zealand, it can be reasonably assumed that during the late Pleistocene, many of the carbonate outcrops observed for this study were well above sea level as a result of glacioueustasy and in a wholly-vadose environment, free of direct marine influence. In such a setting, exposed limestone outcrops can develop an extensive and mature epikarst. In dense, telogenetic limestones, such an epikarst consists of dissolutionally-enlarged joints, bare bedrock surfaces that 
develop rillenkarren and related dissolutional fretwork, and soil-covered bedrock where water is held against the rock as if in a sponge and smooth, curvilinear dissolutional forms are produced. When sea level rises, and these outcrops are partially inundated by marine waters, these epikarst features are overprinted by marine erosion, especially bioerosion in the intertidal zone. Soil and other infill material in the dissolutional fissures and on the bedrock surface can be stripped away by wave action, exposing previously buried dissolutional forms. Any mixing dissolution that occurs in this environment may be difficult to separate from earlier vadose dissolutional processes in the former subsoil epikarst, and modern marine erosion processes. The outcrop at Raglan Harbour shows this superposition of forms extremely well (Fig 4). Despite all the overprinting at Raglan, phreatic tubes and tube segments were abundant and well placed to have formed by mixing dissolution in a coastal setting. But flank margin caves larger than tubes a few meters in length were not observed. Outcrops such as at Whirinaki (Fig 9 and 10), where the carbonate unit is overlain by a fine-grained clastic unit, and no epikarst has had a chance to develop, the results of flank margin cave development are more easily observed. At Waipu Cove (Fig. 12) the epikarst has been overprinted by coastal processes, but tube development and widening of joints at a specific horizon on some outcrops presents the opportunity that these voids are small flank margin caves.

The flank margin caves observed in the various North and South Island outcrops came in a variety of forms and sizes. The largest flank margin caves were found at Kaikoura (Fig. 23 to 28). While this may represent a higher degree of sea-level stability than elsewhere, the highly-fractured nature of the carbonate rock created a porous and permeable environment. The telogenetic Amuri Limestone was able to function more like a porous and permeable eogenetic rock because of the very large number of flow pathways such fracturing produced. The location of the Kaikoura caves on a peninsula, in isolated limestone points jutting outward from that peninsula, argue against the caves being truncated fragments of past conduit flow caves. No recharge area exists for conduit flow caves in this setting. The Kaikoura Peninsula and limestone points are of a size similar to those of the eolian ridges of the Bahamas, which host flank margin caves. Despite the multiple flow paths the fractured Amuri Limestone presents, the main cave trends still follow master joint sets within the bedrock. A similar pattern of cave development occurred at Limestone Creek Through Cave on the west coast of South Island, where one flank margin cave also transects a small limestone point (Fig. 18 and 19). At both Limestone Creek Through Cave and
Kaikoura, the caves contain well-developed phreatic dissolutional features, no high-velocity turbulent flow indicators, and numerous blind or dead-end passages and chambers.

The Tube City outcrop at Limestone Creek (Fig. 20 and 21) demonstrates one of the main tenants of flank margin cave development, which is the headward migration of the mixing front up the available flow path. At Tube City, phreatic tubes of 1 to $2 \mathrm{~m}$ diameter follow joints inward and then abruptly taper and end, with the joint trace continuing inland. This abrupt change from tube to joint is where the mixing front was at the time sea level shifted position relative to the outcrop, and the tube was drained and mixing dissolution ceased. The presence of flowstone material in these tubes indicates that after sea level fell away and the caves drained, they were sealed chambers capable of forming hard, dense calcite speleothems. Cliff retreat caused by wave energy (Fig. 20B) has breached these small flank margin caves and opened them for inspection. The regular spacing of these tubes along the outcrop face is another indication of diffuse flow of fresh water in a lens, such that mixing dissolution occurred across the face of the original rock outcrop wherever a favorable joint allowed sufficient fresh-water input to the lens margin.

Regular spacing of phreatic caves is also evident at Pohara and Paturau River on South Island (Fig. 13 to 16), and at Whirinaki and Kawhia Harbour on North Island (Fig. 6 to 9). Kawhia Harbour is especially compelling, as small dissolution tubes and one large flank margin cave exist in the current inter- and supra-tidal environment, while the hill above has a literal ring of small caves at approximately similar elevations near the crest of the hill. This hill, at a higher sea-level position, would have been an island. To explain these Kawhia Harbour caves as truncated fragments of a distributary conduit flow cave system would place a very high density of unconnected caves in a very small area. However, the presence of ignimbrite in karst depressions adjacent to this hill speaks to a long time of karst activity in this area, and truncation of an ancient complex conduit-flow cave system cannot be discounted.

The presence of relatively delicate phreatic dissolutional features in voids found in coastal carbonates is a good indicator of flank margin cave development. At Paturau River, flank margin caves have been breached by modern coastal processes. Preserved features such as bell holes, small bedrock pillars, and dissolutional fretwork indicate that phreatic voids have been breached by wave erosion. The presence of these voids as discrete chambers, isolated from one another, and the absence of high-velocity turbulent flow markings, indicate that these Paturau River voids are breached flank margin caves. 
Indicators of tectonic movement - Many of the flank margin caves described, such as at Kaikoura and Whirinaki, are elongated in the vertical direction. Classic flank margin caves from the Bahamas are noted for their wide horizontal extent, but their small vertical extent, an outcome of development in the thin, distal margin of a stable fresh-water lens in a very permeable limestone. The key here is lens stability. If the lens is migrating as a result of sea-level change, then the dissolutional environment migrates vertically as well. Too fast a lens migration, and no macroscopic voids develop, as during Pleistocene glacioesutatic changes in the Bahamas, where caves are found at the elevations of the sea-level highstands and lowstands only. But if lens migration is slow, the dissolutional environment also migrates slowly, leaving a vertically extended void behind. Because the lens is resident at any elevation for only a short time period, the width of the void is small. This void width migrates as the lens migrates. Jumps and discontinuities of this vertical enlargement, especially if mimicked by many voids in an outcrop, are a measure of a sudden jump in lens position. The small size of most observed flank margin caves, and the vertically-extended nature of caves in some outcrops, speaks to the rapid tectonic movement of these carbonate outcrops in New Zealand. The regular, circular tubes found in other outcrops, indicate stable sea-level conditions followed by sea level change too rapid to create a macroscopic void. In these outcrops, such as Tube City at Limestone Creek (Fig. 20 and 21), a single sea-level pause is recorded. Tectonics in New Zealand is complicated (e.g. Williams, 2004), and every site discussed has had a different tectonic history. Some caves, such as at Whirinaki, could be Holocene in origin; others, such as at Kaikoura, appear to be Pleistocene in origin.

Does New Zealand have flank margin caves? - If it is assumed that freshwater is discharged diffusely from the land to the sea in coastal locations, then it can also be assumed that mixing of fresh water and sea water will occur. If the rock units present in the coastal location are carbonate rocks, it is reasonable to also assume that mixing dissolution will occur to some extent. In eogenetic carbonate rocks, diagenetic immaturity results in a highly porous and permeable behavior across the bulk of the rock material. The results are caves with globular morphologies, and caves that act independently even of close neighbors. Almost without exception, field study of coastal eogenetic carbonate rocks around the world has described flank margin caves with morphologies and characteristics very distinct from conduit-flow stream caves. Conduit-flow stream caves, whether in eogenetic or telogenetic carbonate rocks, tend to follow linear flow paths. In telogenetic coastal carbonate rocks, low matrix permeability and high bedding, joint, and fault permeability restrict diffuse flow to linear pathways. Therefore, flank margin caves in telogenetic carbonate rocks could be expected to have a much more linear pattern than flank margin caves in eogenetic carbonate rocks. As a result, in telogenetic carbonate rocks, differentiating between senescent flank margin caves, and fragmented and degraded conduit-flow stream caves, can be difficult. Overprinting by epikarst processes, and by marine physical processes, can add to the difficulty. Despite these difficulties, is there any reason to assume that mixing dissolution will not occur in coastal telogenetic carbonate rocks? In the absence of a reason to disbelieve the existence of telogenetic flank margin caves, the question becomes how are they configured, and then, how are they identified? The observations presented here are an attempt to answer that question. It is the opinion of the authors that flank margin caves have developed in the coastal carbonate rocks of New Zealand, and that the examples presented demonstrate they can be differentiated in the field from other cave types, both karst and pseudokarst.

\section{SUMMARY}

Analysis of nine coastal carbonate locations on North and South Island, New Zealand, indicate that flank margin caves do exist on these two islands. The caves are much smaller than many Bahamian flank margin caves, which are known to have formed in 12,000 years or less. This small size is the result of denser and less permeable telogenetic carbonate host rocks, and the rapid changes in sea level that occur in this environment, where glacioeustasy is overprinted by very active tectonics. The fresh-water lenses in New Zealand were in a single position for an amount of time much less than that available in the tectonicallystable Bahamas. Most of the flank margin caves described have passage patterns that reflect the controls of dissolution provided in dense teleogenetic rocks by bedding planes, joints, and faults. The largest flank margin caves occur where tectonics has caused rock fracturing at the centimetre scale, creating a very porous and permeable rock condition for the fresh-water lens. Epikarst development in teleogenetic carbonate rocks creates a dissolutional environment, that when overprinted by marine processes, makes it difficult to 
assess the role of mixing dissolution in creation of the observed caves.

The presence of flank margin caves, and their shape and configuration, provide useful information about sea-level position stability. While the absence of flank margin caves in a carbonate outcrop proves little, vertically-elongated flank margin caves, or multiple but discrete horizons of flank margin caves, indicate sea-level change that was rapid but not too rapid. If this threshold of sea-level change rate could be quantified, then flank margin caves would offer a different measure of tectonic activity. The mere presence of flank margin caves in a carbonate outcrop is an indication of subaerial exposure of that carbonate outcrop, such that it received meteoric recharge and built a fresh-water lens. The presence of high-elevation $(375 \mathrm{~m})$ flank margin cave remnants on Te Mata Peak, North Island, indicates that the carbonate unit was subaerially exposed while in a coastal setting. The survival of flank margin caves on Te Mata, and at the other described outcrops, is a measure of the rapid rate of uplift and/or slope or cliff retreat in that area. Because flank margin caves develop in the distal margin of the fresh-water lens, they are vulnerable to exposure and subsequent complete destruction by erosion. The existence of senile flank margin caves, especially in currently interior locations, puts a boundary condition on denudation rates in that area.

The documentation of flank margin caves in New Zealand for the first time is not just an exercise in stamp collecting. The shape, size, abundance, and mere existence of flank margin caves provide geoscientists with information about a variety of tectonic, surficial, and hydrological processes.

\section{ACKNOWLEDGMENTS}

The authors thank Mississippi State University for providing John Mylroie with a sabbatical, and Joan Mylroie with a leave of absence, so that this research could be done. The University of Waikato in Hamilton, New Zealand, provided logistical support for the project. Stephanie Nyman provided essential ground transport on North Island. The Department of Geosciences, Missis- sippi State University, assisted with travel costs. Leif Mylroie and Max Oulton are thanked for map production. Paul Williams is especially thanked for leading field trips, providing insight on New Zealand geology and caves, exceptional hospitality, and overall enjoyable discussions that helped guide this research.

\section{REFERENCES}

Back, W., B.B. Hanshaw, J.S. Herman, \& J.N. Van Driel, 1986: Differential dissolution of a Pleistocene reef in the ground-water mixing zone of coastal Yucatan, Mexico: Geology, 14, 137-140.

Bögli, A., 1980: Karst Hydrology and Physical Speleology, p. 284, Springer Verlag, New York.

Bottrell, S.H., J.L. Carew, \& J.E. Mylroie, 1993: Bacterial sulphate reduction in flank margin environments: Evidence from sulphur isotopes. In: White, B. ed., Proceedings of the Sixth Symposium on the Geology of the Bahamas, Port Charlotte, Florida, Bahamian Field Station, 17-21.

Carew, J.L., \& J.E. Mylroie, 1995: Quaternary tectonic Stability of the Bahamian Archipelago: Evidence from fossil coral reefs and flank margin caves: Quaternary Science Reviews, 14, 144-153.
Caron, V., C.S. Nelson, \& P.J.J. Kamp, 2006: Microstratigraphy of calcite cements in Pliocene cool-water limestones, New Zealand: relationship to sea-level, burial and exhumation events. In Pedley, H.M., and Carannante, G., eds., Cool-Water Carbonates: Depositional Systems and Palaeoenvironmental Controls. Geological Society, London, Special Publications 255, 337-365.

Chen, J.H., H.A. Curran, B. White, \& G.J. Wasserburg, 1991: Precise chronology of the last interglacial period: ${ }^{234} \mathrm{U}-230 \mathrm{Th}$ data from fossil coral reefs in the Bahamas: Geological Society of America Bulletin, 103, 82-97.

Choquette, P.W., \& L.C. Pray, 1970: Geologic nomenclature and classification of porosity in sedimentary carbonates: American Association Petroleum Geologists Bulletin, 54, 2, 207-250. 
Dasher, G.R., 1994: On Station: A Complete Handbook for Surveying and Mapping Caves, National Speleological Society, p 242, Huntsville, Alabama.

Dreybrodt, W., 2000: Equilibrium chemistry of karst water in limestone terranes, In Klimchouk, A.B., Ford, D.C., Palmer, A.N. \& Dreybrodt, W., eds., Spelogenesis - Evolution of karst aquifers: National Speleological Society, Huntsville, Alabama, 126-135.

Folk, R.L., H.H. Roberts, \& C.H. Moore, 1973: Black phytokarst from Hell, Cayman Islands, British West Indies: Geological Society of America Bulletin, 84, 2351-2360.

Frank, E.F., J.E. Mylroie, J., Troester, E.C. Alexander, \& J.L. Carew, 1998: Karst development and speleologensis, Isla de Mona, Puerto Rico: Journal of Cave and Karst Studies, 60, 2, 73-83.

Hull, A.G., 1990: Tectonics of the 1931 Hawkes Bay earthquake. New Zealand Journal of Geology and Geophysics 33, 309-322.

Jenson, J. W., T.M. Keel, J.R. Mylroie, J.E. Mylroie, K.W. Stafford, D. Taborosii, C. Wexel, 2006: Karst of the Mariana Islands: The interaction of tectonics, glacioeustasy and fresh-water/sea-water mixing in island carbonates: Geological Society of America Special Paper 404, 129-138.

Kelley, K., J.E. Mylroie, J.R. Mylroie, C. Moore, P.J. Moore, L. Collins, V. Ersek, I. Lascu, M. Roth, R. Passion, \& C. Shaw, 2006: Eolianites and Karst Development in the Mayan Riviera, Mexico. In Davis, R.L., \& Gamble, D.W., eds., Proceedings of the Twelfth Symposium on the Geology of the Bahamas and Other Carbonate Regions, Gerace Research Center, San Salvador, Bahamas, 88-99.

Lace, M. J., 2008: Coastal caves of Puerto Rico: Journal of Coastal Research, 24, 508-518.

McNeill, D.F., 2005: Accumulation rates from well-dated late Neogene carbonate platforms and margins: Sedimentary Geology, 175, 73-87.

Moore, P.J., J.H. Martin, \& J.E. Mylroie, 2007 (abstract): Rapid development of secondary porosity within freshwater lenses of carbonate islands: Geological Society of America, Abstracts with Programs, 39, 6, 467.

Mylroie, J.E. \& J.L. Carew, 1990: The Flank Margin Model for Dissolution Cave Development in Carbonate Platforms: Earth Surface Processes and Landforms, 15, 413-424.

Mylroie, J.E., \& J.L. Carew, 1995: Chapter 3, Karst development on carbonate islands. In Budd, D.A, Harris, P.M. \& Saller, A., eds., Unconformities and Porosity in Carbonate Strata: American Association of Petroleum Geologists Memoir 63, 55-76.
Mylroie, J.E., J.L. Carew, \& H.L. Vacher, 1995: Karst development in the Bahamas and Bermuda. In Curran, H.A. and White, B., eds., Geological Society of America Special Paper 300, Terrestrial and Shallow Marine Geology of the Bahamas and Bermuda, 251267.

Mylroie, J.E. \& J.R. Mylroie, 2007a, Development of the Carbonate Island Karst Model: Journal of Cave and Karst Studies, 69, 59-75.

Mylroie, J.E., \& J.R. Mylroie, 2007b (abstract), Quaternary geologic interpretations from flank margin caves, Kangaroo Island, Australia: Geological Society of America, Abstracts with Programs, 39, 6, 78.

Nelson, C.S., 1978: Temperate shelf carbonate sediments in the Cenozoic of New Zealand. Sedimentology 25, 737-771.

Nelson, C.S., G.J. Harris, \& H.R. Young, 1988: Burialdominated cementation in non-tropical carbonates of the Oligocene Te Kuiti Group, New Zealand. Sedimentary Geology 60, 233-250.

Nelson, C.S., P.R. Winefield, S.D. Hood, V. Caron, A. Pallentin, \& P.J.J. Kamp, 2003: Pliocene Te Aute limestones, New Zealand: Expanding concepts for cool-water shelf carbonates. New Zealand Journal of Geology and Geophysics 46, 407-424.

Neuendorf, K.K.E., J.P. Mehl, \& J.A. Jackson, 2005: Glossary of Geology, Fifth Edition, American Geological Institute, p. 779.

Owen, A.M., 2007: Tafoni caves in Quaternary carbonate eolianites: Examples from The Bahamas. Masters thesis, Mississippi State University, p.187.

Palmer, A.N., 1991: Origin and morphology of limestone caves: Geological Society of America Bulletin, 103, $1-25$.

Plummer. L.N., 1975: Mixing of sea water with calcium carbonate ground water. In E. H. T. Whitten, ed., Quantitative studies in geological sciences: Geological Society of America Memoir 142, 219-236.

Pillans, B., 1986: A late Quaternary uplift map for North Island, New Zealand. In W.I. Reilly \& B. E. Harford, eds., Recent crustal movements of the Pacific region. Royal Society of New Zealand Bulletin 24, 409-417.

Proctor, C.J., 1988: Sea-level related caves on Berry Head, South Devon: Cave Science, 15, 2, 39-49.

Raeisi, E., \& J.E. Mylroie, 1995: Hydrodynamic behavior of caves formed in the fresh-water lens of carbonate islands: Carbonates and Evaporites, 10, 2, 207-214.

Roth, M. J., 2004: Inventory and geometric analysis of flank margin caves of The Bahamas. Masters thesis, Mississippi State University, p. 117. 
Roth, M. J., J.E. Mylroie, J.R. Mylroie, V. Ersek, C.C. Ersek, \& J.L. Carew, 2006: Flank Margin Cave Inventory of the Bahamas. In Davis, R.L., and Gamble, D.W., eds., Proceedings of the Twelfth Symposium on the Geology of the Bahamas and Other Carbonate Regions, Gerace Research Center, San Salvador, Bahamas, 153-161.

Taboroši, D., J.W. Jenson, \& J.E. Mylroie, 2004: Karren features in island karst: Guam, Mariana Islands: Zeitschrifft fur Geomorphologie. N.F. 48, 369-389.

Taboroši, D., J.E. Mylroie, \& K. Kirakawa, 2006: Stalactites on tropical cliffs: Remnants of breached caves or subaerial tufa deposits? Zeitschrifft fur Geomorphologie, 50, 117-139.

Vacher, H.L.\& J.E. Mylroie, 2002: Eogenetic karst from the perspective of an equivalent porous medium: Carbonates and Evaporites: 17, 2, 182-196.
Walker, L.N., 2006: The caves, karst and geology of Abaco Island, Bahamas. Masters thesis, Mississippi State University, 241 p. http://sun.library.msstate.edu/ ETD-db/theses/available/etd 03292006 153441/unrestricted/LWalker_Geology_Abaco.pdf

Waterstrat, W. J., 2007: Morphometric differentiation of flank margin caves and littoral, or sea caves. Masters thesis, Mississippi State University, 201 p. http://library.msstate.edu/etd/show.asp?etd=etd 04052007 150907

White, S.Q., K. Grimes, \& J.E. Mylroie, 2007: (abstract) The earliest time of karst cave formation. Time In Karst Symposium, Postojna, Slovenia, CD.

Williams, P.W., 2004: The evolution of the mountains of New Zealand. Oxford University Press, New York, 89-106. 